Prepared in cooperation with the National Park Service

\title{
Effects of Streamflows on Stream-Channel Morphology in the Eastern Niobrara National Scenic River, Nebraska, 1988-2010
}

Scientific Investigations Report 2016-5004 
Cover. View of Niobrara River looking downstream from bluff near Mariaville, Nebr. Photograph taken by Jason Alexander, U.S. Geological Survey.

Right side photographs, top to bottom. Aerial photograph of Niobrara River near Meadville, Nebr., in 1999. Photograph from U.S. Geological Survey. Aerial photograph of Niobrara River near Meadville, Nebr., in 2003. Photograph from U.S. Department of Agriculture. 


\section{Effects of Streamflows on Stream- Channel Morphology in the Eastern Niobrara National Scenic River, Nebraska, 1988-2010}

By Nathaniel J. Schaepe, Jason S. Alexander, and Kiernan Folz-Donahue

Prepared in cooperation with the National Park Service

Scientific Investigations Report 2016-5004 


\title{
U.S. Department of the Interior SALLY JEWELL, Secretary
}

\section{U.S. Geological Survey Suzette M. Kimball, Director}

\author{
U.S. Geological Survey, Reston, Virginia: 2016
}

For more information on the USGS - the Federal source for science about the Earth, its natural and living resources, natural hazards, and the environment—visit http://www.usgs.gov or call 1-888-ASK-USGS.

For an overview of USGS information products, including maps, imagery, and publications, visit http://www.usgs.gov/pubprod/.

Any use of trade, firm, or product names is for descriptive purposes only and does not imply endorsement by the U.S. Government.

Although this information product, for the most part, is in the public domain, it also may contain copyrighted materials as noted in the text. Permission to reproduce copyrighted items must be secured from the copyright owner.

Suggested citation:

Schaepe, N.J., Alexander, J.S., and Folz-Donahue, Kiernan, 2016, Effects of streamflows on stream-channel morphology in the eastern Niobrara National Scenic River, Nebraska, 1988-2010: U.S. Geological Survey Scientific Investigations Report 2016-5004, 30 p., http://dx.doi.org/10.3133/sir20165004.

ISSN 2328-0328 (online) 


\section{Contents}

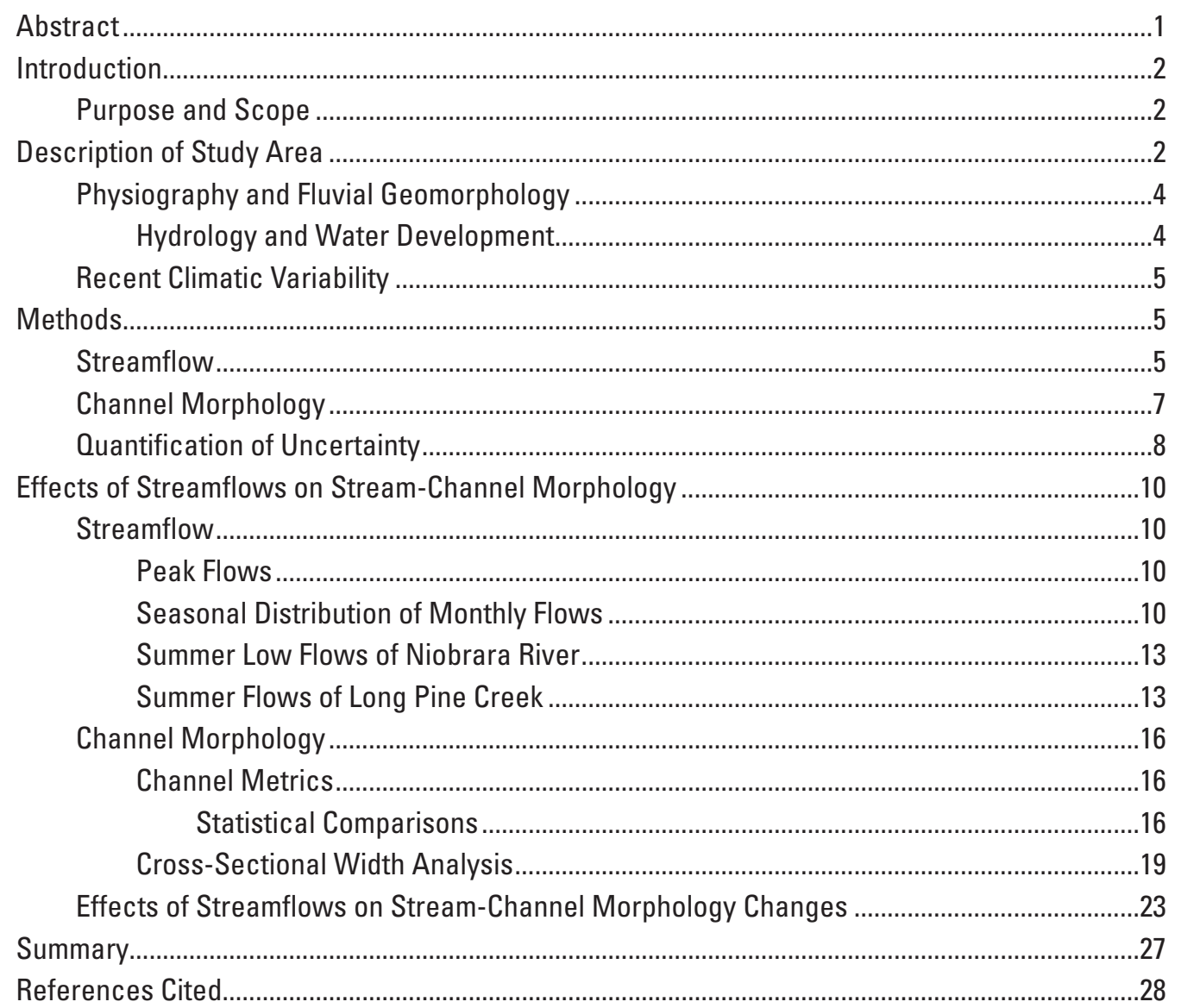




\section{Figures}

1. Map showing study segments of eastern Niobrara National Scenic River and surrounding area in north-central Nebraska.

2. Graph showing summary of monthly mean streamflow of Niobrara River near Sparks, Nebraska, and Palmer Drought Severity Index for north-central region of Nebraska, water years 1946-2010.

3. Map showing digitized features on 2003 aerial photograph of example segment of eastern Niobrara National Scenic River in north-central Nebraska

4. Graph showing annual series of peak flows for Niobrara River near Sparks, Nebraska, 1988-2010.

5. Graphs showing median monthly streamflows for selected streamgages near the study area .....

6. Graphs showing annual measures of streamflow of Niobrara River near Sparks, Nebraska, 1988-2010.

7. Graphs showing annual measures of streamflow for Long Pine Creek near Riverview, Nebraska, 1988-2010.

8. Graphs showing channel-width metrics and total area of islands plus incipient flood-plain surfaces of the eastern Niobrara National Scenic River, Nebraska, for 1993, 1999, 2003, 2006, and 2010.

9. Boxplot diagrams of the frequency distribution of cross-section scale changes in channel-width metrics from aerial photography between consecutive pairs of study years, study segment 1, eastern Niobrara National Scenic River, Nebraska, 1993-2010

10. Boxplot diagrams of the frequency distribution of cross-section scale changes in channel-width metrics from aerial photography between consecutive pairs of study years, study segment 2, eastern Niobrara National Scenic River, Nebraska, 1993-2010

11. Boxplot diagrams of the frequency distribution of cross-section scale changes in channel-width metrics from aerial photography between consecutive pairs of study years, study segment 3, eastern Niobrara National Scenic River, Nebraska, 1993-2010

12. Graph showing longitudinal trend in total channel width for reach in study segment $1,53,000$ to 63,000 meters upstream from study area boundary, eastern Niobrara National Scenic River, Nebraska, 1993-99, highlighting an area of bank erosion

13. Maps showing channel change delineated on aerial photographs of eastern Niobrara National Scenic River, Nebraska, highlighting areas that underwent substantial bank erosion in a part of segment 1

14. Graph showing longitudinal trend in total channel width for reach in study segments 1 and 2, 40,000 to 50,000 meters upstream from study area boundary, eastern Niobrara National Scenic River, Nebraska, 1999-2003, highlighting an area of island attachment to bank

15. Maps showing channel change delineated on aerial photographs of eastern Niobrara National Scenic River, Nebraska, highlighting an area of island attachment to a bank in a part of segment 1 ..... 


\section{Tables}

1. Characteristics of aerial photography used for calculating channel metrics, eastern Niobrara National Scenic River, 1993-2010...

2. Average areal uncertainty of digitized features in the eastern Niobrara National Scenic River, Nebraska, 1993-2010

3. Statistical analysis test results of measured active channel width between 1993 and $\mathbf{2 0 1 0}$ for three segments of the eastern Niobrara National Scenic River...

4. Measures of channel morphology for three segments of the eastern Niobrara National Scenic River, north-central Nebraska, as measured from aerial imagery for selected years, 1993-2010.

\section{Conversion Factors}

[International System of Units to Inch/Pound]

\begin{tabular}{|c|c|c|}
\hline Multiply & By & To obtain \\
\hline \multicolumn{3}{|c|}{ Length } \\
\hline centimeter $(\mathrm{cm})$ & 0.393701 & inch (in.) \\
\hline meter $(\mathrm{m})$ & 3.281 & foot $(\mathrm{ft})$ \\
\hline kilometer (km) & 0.6212 & mile (mi) \\
\hline \multicolumn{3}{|c|}{ Area } \\
\hline square meter $\left(\mathrm{m}^{2}\right)$ & 0.000247 & acre \\
\hline square kilometer $\left(\mathrm{km}^{2}\right)$ & 247.105 & acre \\
\hline square meter $\left(\mathrm{m}^{2}\right)$ & 10.76 & square foot $\left(\mathrm{ft}^{2}\right)$ \\
\hline square kilometer $\left(\mathrm{km}^{2}\right)$ & 0.3861 & square mile $\left(\mathrm{mi}^{2}\right)$ \\
\hline \multicolumn{3}{|c|}{ Flow rate } \\
\hline cubic foot per second $\left(\mathrm{ft}^{3} / \mathrm{s}\right)$ & 0.0283 & cubic meter per second $\left(\mathrm{m}^{3} / \mathrm{s}\right)$ \\
\hline \multicolumn{3}{|c|}{ Volume } \\
\hline cubic kilometer $\left(\mathrm{km}^{3}\right)$ & 0.2399 & cubic $\mathrm{mi}\left(\mathrm{mi}^{3}\right)$ \\
\hline
\end{tabular}

A water year is the 12-month period from October 1 through September 30 of the following year and is designated by the calendar year in which it ends.

\section{Datum}

Vertical coordinate information is referenced to the North American Vertical Datum of 1988 (NAVD 88). 


\section{Abbreviations}

$\begin{array}{ll}\text { GIS } & \text { geographic information system } \\ \text { lidar } & \text { light detection and ranging } \\ \text { NPS } & \text { National Park Service } \\ \text { NWIS } & \text { National Water Information System } \\ \text { PDSI } & \text { Palmer Drought Severity Index } \\ \text { RMSD } & \text { root-mean-square difference } \\ \text { USFWS } & \text { U.S. Fish and Wildlife Service } \\ \text { USGS } & \text { U.S. Geological Survey } \\ \text { WSRA } & \text { Wild and Scenic Rivers Act }\end{array}$




\title{
Effects of Streamflows on Stream-Channel Morphology in the Eastern Niobrara National Scenic River, Nebraska, 1988-2010
}

\author{
By Nathaniel J. Schaepe, Jason S. Alexander, and Kiernan Folz-Donahue
}

\section{Abstract}

The Niobrara River is an important and valuable economic and ecological resource in northern Nebraska that supports ecotourism, recreational boating, wildlife, fisheries, agriculture, and hydroelectric power. Because of its uniquely rich resources, a 122-kilometer reach of the Niobrara River was designated as a National Scenic River in 1991, which has been jointly managed by the U.S. Fish and Wildlife Service and National Park Service. To assess how the remarkable qualities of the National Scenic River may change if consumptive uses of water are increased above current levels, the U.S. Geological Survey, in cooperation with the National Park Service, initiated an investigation of how stream-channel morphology might be affected by potential decreases in summer streamflows. The study included a 65-kilometer segment in the wide, braided eastern stretch of the Niobrara National Scenic River that provides important nesting habitat for migratory bird species of concern to the Nation.

The study focused on three river segments, separated at the confluences with two tributaries, Plum Creek and Long Pine Creek. With an overall temporal scope of 1988-2010 that includes a short interval preceding and a long interval following the Niobrara National Scenic River Designation Act of 1991, the study analyzed five separate time periods: 1988-93, 1994-99, 2000-3, 2004-6, and 2007-10, each of which ended with a year in which aerial photography coverage was available.

Streamflow duration was analyzed for one streamgage upstream from the study area and two streamgages on tributary streams within the study area. Summer streamflows (July, August, and September) were targeted for analysis because median flows of the Niobrara River are lowest during those 3 months. In addition, peak flows during the study period were used to estimate bankfull discharge, which is one determinant of channel dimensions.

Changes in channel morphology were examined using aerial photographs from 1993, 1999, 2003, 2006, and 2010 to measure channel width, area of islands, and incipient floodplain surfaces, and to compute the braided index. Channel metrics were computed for each photography year and summarized by river segment. Additionally, at fixed-location cross sections, photography analysis identified localized geomorphic change to infer processes. Accuracy of geomorphic feature classification was estimated and the root-mean-square difference (RMSD) between aerial photographs was calculated to determine associated errors in channel metric calculations. The horizontal accuracy of boundaries delineated in the classification was estimated as 5 meters $(\mathrm{m})$ for boundaries based on 1993 aerial photography and $4 \mathrm{~m}$ for all other aerial photography. The RMSD between aerial photography years ranged from $3.04 \mathrm{~m}$ to $4.16 \mathrm{~m}$.

The largest measurable changes in channel metrics were measured between 1993 and 1999 and between 1999 and 2003. Between 1993 and 1999, average total channel width increased by $9 \mathrm{~m}$ ( 3 percent) and $14 \mathrm{~m}$ ( 5 percent) in segments 2 and 3, respectively; average active channel width increased by $13 \mathrm{~m}$ ( 5 percent) in segment 3 and decreased by $6 \mathrm{~m}$ (4 percent) in segment 1; and incipient flood-plain-surface area increased by 40,44 , and 33 percent in segments 1,2 , and 3 , respectively. Changes in channel metrics between 1999 and 2003 included a decrease in average total channel width of $14 \mathrm{~m}$ ( 5 percent) in segment 2 ; a decrease in active channel widths of $8 \mathrm{~m}$ ( 3 percent) and $6 \mathrm{~m}$ ( 2 percent) in segments 2 and 3, respectively; and an increase of $5 \mathrm{~m}$ ( 3 percent) in segment 1 . Incipient flood-plain areas decreased by 22 and 33 percent in segments 1 and 2, respectively, and increased by 42 percent in segment 3 .

Large changes were measured between 1993 and 1999, and between 1999 and 2003, at many of the fixed-location cross sections. Large changes (that is, greater than 25 percent) in total channel width were measured in all three segments between 1993 and 1999 and again between 1999 and 2003; large increases were dominant between 1993 and 1999 and large decreases were dominant between 1999 and 2003. Segment 1 was the most susceptible to localized changes as there was only one period (between 2003 and 2006) in which the active channel width largely changed in fewer than 10 percent of the cross sections.

Changes in channel metrics generally corresponded to changes in streamflow conditions, but other than changes in 
incipient flood-plain area, these changes were small and were not measured in all three segments simultaneously. Increases in total channel width (except in segment 1) and incipient flood-plain area between 1993 and 1999 corresponded to increases in streamflow. Channel narrowing (except in segment 1) between 1999 and 2003 corresponded to lower summer streamflows and extended durations of very low summer streamflow. Although the pattern of low summer streamflow and extended durations of very low summer streamflow continued during the 2004-6 period and at the beginning of the 2007-10 period, no further narrowing was measured. Consistent tributary summer inflows help to explain the resistance of segments 2 and 3 to further narrowing. Because segment 1 is already much narrower than segments 2 and 3 , its average current velocity is likely to be swifter and, therefore, competent to offset further effects of the processes that led to its narrowness.

\section{Introduction}

The Niobrara National Scenic River in north-central Nebraska (fig. 1) is an important economic and ecological resource that supports ecotourism, recreational boating, wildlife, fisheries, hydroelectric power, and agriculture. It has a diverse ecosystem with many plant and animal species and is used as a stopover for migratory bird species that include several threatened or endangered species (Ducey, 1989). The Niobrara National Scenic River was established by the Niobrara Scenic River Designation Act of 1991 to protect this valuable resource. The Niobrara Scenic River Designation Act cited protections of the Niobrara River under the Wild and Scenic Rivers Act of 1968 (WSRA), and administration of the Niobrara Scenic River Designation Act was delegated to the U.S. Fish and Wildlife Service (USFWS) and the National Park Service (NPS). Under the specific language of the WSRA (Public Law 90-542; 16 U.S.C. 1271 et seq., 1968):

It is hereby declared to be the policy of the United States that certain selected rivers of the Nation which, with their immediate environments, possess outstandingly remarkable scenic, recreational, geologic, fish and wildlife, historic, cultural, or other similar values, shall be preserved in freeflowing condition, and that they and their immediate environments shall be protected for the benefit and enjoyment of present and future generations.

Much of the Niobrara River is west of the 100th meridian, which roughly separates temperate climates to the east from the semi-arid or steppe climates to the west (Powell, 1879). The semi-arid agricultural lands adjacent to and upstream from the Niobrara National Scenic River generally require irrigation for dependable crop yields, and future expansion of irrigated agriculture may increase consumptive use of water supplies such that some tributary inflows that presently sustain the Niobrara National Scenic River could be placed at risk of becoming seasonally intermittent.

The juxtaposition of irrigated agriculture and federally mandated protections of the Niobrara National Scenic River represents a potential long-term conflict over water in the Niobrara River. Scientific information is needed to assess how potential changes in streamflows from increased consumptive uses may affect the Niobrara National Scenic River. In cooperation with the NPS Water Rights Branch, the U.S. Geological Survey (USGS) initiated a study to investigate how channel morphology in the eastern part of the Niobrara National Scenic River might be affected by potential decreases in summer streamflows. The eastern region of the Niobrara National Scenic River was selected because the river channel is wide and braided, provides important nesting and roosting habitat for Federal- and State-listed bird species, and a change in river stage of as little as 50 centimeters $(\mathrm{cm})$ can inundate or expose a large fraction of the river bed.

This study focused on channel morphology changes on the Niobrara River associated with changes in streamflow, especially low flows, for two reasons. First, the Niobrara River is strongly dependent on groundwater seepage, making its base flows potentially vulnerable to the effects of pumpage from the shallow alluvial aquifers that recharge the river (Soenksen and others, 2010). Second, irrigation withdrawals from the river are temporally coincident with the typically low-flow months from July through September, making it a period of particular vulnerability.

\section{Purpose and Scope}

The purpose of this report is to present the results from a study of the potential effects of variable streamflows on stream-channel morphology along a 65-kilometer $(\mathrm{km})$ segment of the eastern Niobrara National Scenic River. Special consideration is given to address how periods of decreased low flows may have preceded periods of channel narrowing. The study focused on the time period preceding and following the designation of the Niobrara River as a National Scenic River in 1991, specifically 1988-2010. This period was split into five separate analysis periods based on the availability of aerial photography: water years 1988-93, 1994-99, 2000-03, 2004-6, and 2007-10. A water year is the 12-month period from October 1 through September 30 of the following year and is designated by the calendar year in which it ends.

\section{Description of Study Area}

The study area extends $65 \mathrm{~km}$ along the Niobrara River from Norden to Mariaville, Nebraska (fig. 1). The studied river segments are characterized by a wide, braided channel and a wide valley (Alexander and others, 2010). Tributaries discharging into the study area include Plum and Long Pine 


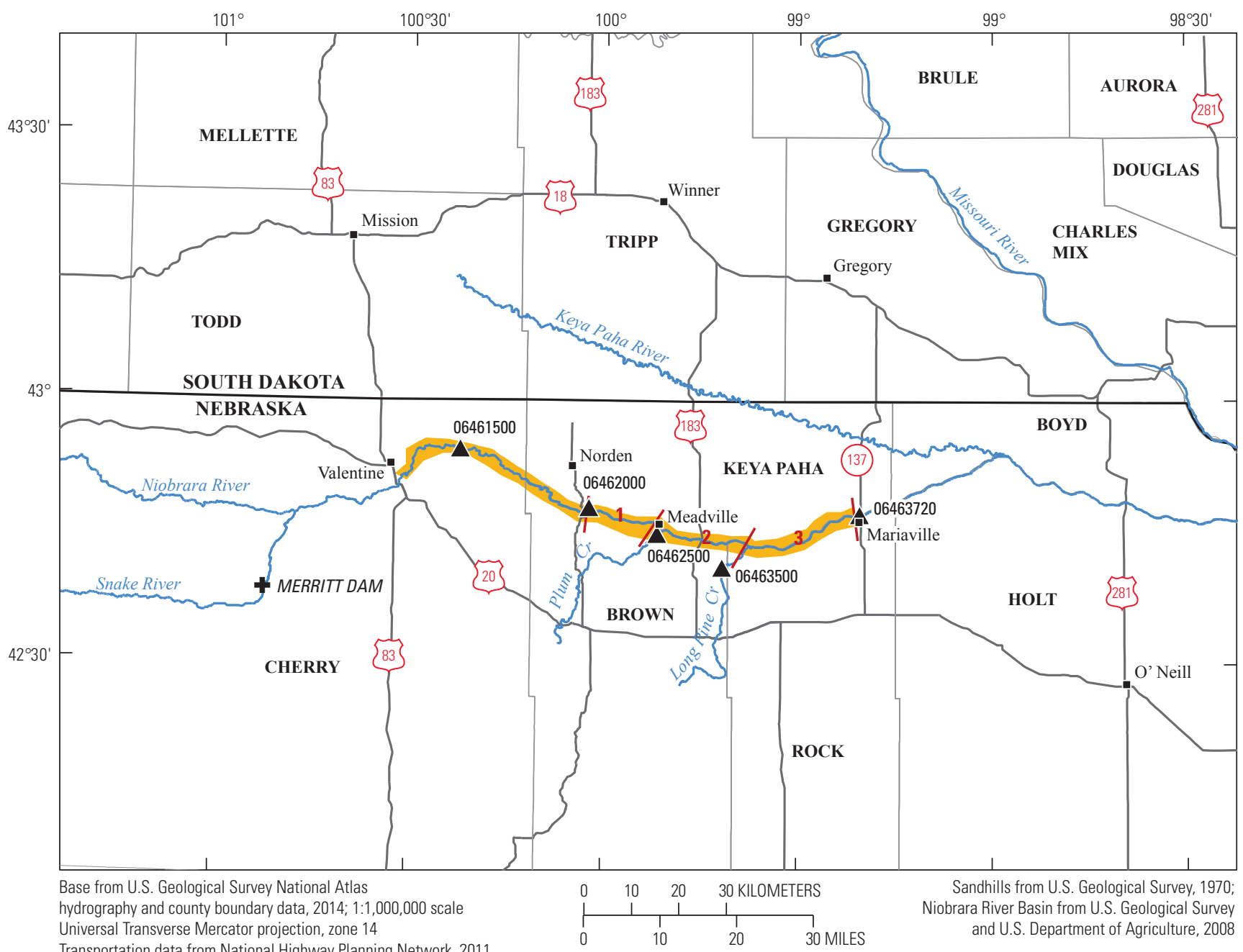

Transportation data from National Highway Planning Network, 2011,

1:100,000 scale, and Nebraska Department of Roads, 1995, 1:24,000 scale

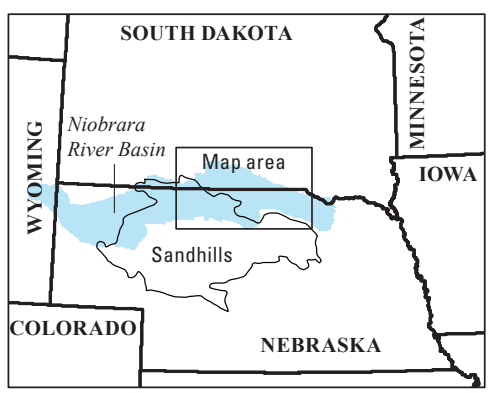

EXPLANATION

06463500 U.S. Geological Survey streamgage

Niobrara National Scenic River

(reach managed by the

National Park Service)

1 / Study river-segment number

Figure 1. Study segments of eastern Niobrara National Scenic River and surrounding area in north-central Nebraska. 
Effects of Streamflows on Stream-Channel Morphology in the Eastern Niobrara National Scenic River, Nebraska

Creeks (fig. 1), each of which contributes roughly 10 percent of the annual streamflow at Mariaville (Fischer, 1987).

The study area was divided into three segments based on the locations of tributary confluences. Segment 1 begins at a county-road bridge south of Norden, Nebr., and ends at the confluence with Plum Creek. Segment 2 begins at the confluence with Plum Creek and ends at the confluence with Long Pine Creek. Segment 3 begins at the confluence with Long Pine Creek and ends at the Nebraska State highway 137 bridge north of Mariaville, Nebr. (fig. 1).

\section{Physiography and Fluvial Geomorphology}

The Niobrara River flows across $900 \mathrm{~km}$ of the Great Plains of North America (Fenneman, 1946) and drains approximately 35,000 square kilometers $\left(\mathrm{km}^{2}\right)$ along its course (Alexander and others, 2010). Although the Niobrara River basin (fig. 1) includes parts of east-central Wyoming and southern South Dakota, most of the drainage basin and main stem of the river lie in north-central Nebraska. Approximately 40 percent of the river basin is within the Nebraska Sand Hills region (hereinafter referred to as "the Sandhills") of the Great Plains (Omernik, 1987), a vast region of wind-blown sand, stabilized by prairie vegetation, mantling Neogene- to Cretaceous-age bedrock (Bleed and Flowerday, 1990). The bedrock units include Brule of the White River Group and Arikaree of Paleogene to Neogene age and Pierre Shale of Late Cretaceous age. Modern basin physiography is the result of initial relief, geologic character, and climatic effects (Schumm, 2005); each of these aspects is considered in turn.

Total relief in the Niobrara River basin is approximately 1,300 meters ( $\mathrm{m}$ ) above the base level altitude at the Missouri River confluence of $370 \mathrm{~m}$ (North American Vertical Datum of 1988 [NAVD 88]). Through geologic time, the multiple levels of terrace deposits along the middle Niobrara Valley indicate there have been periods when the base level fluctuated and valleys were filled to a much greater extent with thick alluvial sequences. In recent time, the river has evacuated most of its alluvium and locally exhibits geologic grade control where resistant bedrock underlies the channel. The modern valley gradient along the Niobrara River averages 0.15 percent (Alexander and others, 2009) between Dunlap Diversion Dam (upstream from and not shown in fig. 1) and the Missouri River confluence.

Along its traverse across northern Nebraska, the physical characteristics of the Niobrara River change with additions of tributary and groundwater inflows and changes in local geologic controls. In eastern Cherry County, the Niobrara transitions from a narrower river confined by bedrock canyon walls to a much wider channel flowing through a wide alluvial valley (Alexander and others, 2010). For the last $200 \mathrm{~km}$ of its length, the Niobrara River channel is complex, flowing in multiple threads separated by islands, broad sand flats, and sandbars (Buchanan, 1981). Although the exact geologic mechanism for the change in channel planform has not been determined, Alexander and others (2010) determined that the channel planform transitions where the bedrock at river level changes from the Brule of the White River Group and Arikaree of Paleogene to Neogene age to the Pierre Shale of Late Cretaceous age.

Buchanan and Schumm (1990) identified streamflow and channel ice formation as the principle geomorphic agents of channel change in the Niobrara River. Ice formation on sandbars can drastically shift channel location from fall to spring. In the fall, the flow becomes shallow and spreads out with no discernible thalweg. During winter, ice forms on shallow sandbars, stabilizing the bars and constricting the flow, which creates a narrow thalweg. As more of the channel freezes, the flow becomes further constricted in the thalweg and scours the bed below (Buchanan and Schumm, 1990). Alexander and others (2010) determined that ice jams caused flooding of the modern, active flood plain and low terraces along the valley bottom. During ice-free periods, streamflow magnitude was identified as the primary agent of geomorphic change. Buchanan (1994) also indicated that peak flows removed vegetation from bars and eroded banks. During periods of low flows, the channel narrowed as islands formed or became attached to the flood plain. Buchanan and Schumm (1990) also noted some narrowing at tributary confluences where flood plains impinge on the main-stem channel.

\section{Hydrology and Water Development}

Because of their high infiltration capacity, the Sandhills are a region of groundwater recharge to the High Plains Aquifer (Szilagyi and others, 2005). Rivers flowing through the Sandhills region are known for small runoff to precipitation ratios and a lagged responsiveness to drought conditions (Wang and others, 2009; Istanbulluoglu and others, 2008; 2012). For example, Istanbulluoglu (2008, p. 30) determined that streamflow measured at the Niobrara River at Sparks (USGS site 06461500 , fig. 1) has a precipitation memory of as many as 5 years, which means streamflow could be higher than average in a normal precipitation year if the previous years were wet, and conversely, if the previous years were dry, streamflow could be lower than normal. The strong linkage between groundwater storage and surface water makes the streams in the Sandhills somewhat resilient to typical 3-4-year duration (Istanbulluoglu, 2008) dry periods, but sensitive to long-term increased consumptive uses of groundwater (Stanton and others, 2010).

Irrigation water demand in the Niobrara River basin has led to increases in groundwater usage and development of streamflow diversions and dams within the Niobrara River basin during the last 75 years (Shaffer, 1975). Approximately 1.082 cubic kilometers $\left(\mathrm{km}^{3}\right)$ of water are currently used in the Niobrara River basin each year to provide water to an estimated 3,215 irrigated $\mathrm{km}^{2}$. Of that irrigated area, approximately 83 percent is irrigated from groundwater sources and 17 percent from surface water (Bureau of Reclamation, 2013). 
Box Butte Dam (upstream from the area shown in fig. 1) on the Niobrara River and Merritt Dam (fig. 1) on the Snake River have had the largest effects on the Niobrara River's hydrology. Box Butte Dam was constructed in 1945 to provide water for the Mirage Flats irrigation project. On average, $0.013 \mathrm{~km}^{3}$ of water are diverted to irrigate approximately $47 \mathrm{~km}^{2}$. Merritt Dam was constructed on the Snake River, the third largest tributary by drainage area to the Niobrara River, to provide water for the Ainsworth Irrigation District (Bureau of Reclamation, 2013). The Ainsworth Irrigation District provides $0.093 \mathrm{~km}^{3}$ (Shultz, 2010) annually from reservoir storage to irrigate $137 \mathrm{~km}^{2}$ (Bureau of Reclamation, 2013). This is approximately 40 percent of the mean annual runoff for the contributing drainage area upstream from Merritt Dam (Bureau of Reclamation, 2013). Since the filling of Merritt Reservoir began in 1964, mean annual streamflows on the Niobrara River downstream from the Snake River have decreased by about 13 percent (Niobrara River near Sparks, Nebr., USGS site 06461500; Istanbulluoglu, 2008) to 15 percent (Niobrara River near Norden, Nebr., USGS site 06462000 [discontinued in 1986]; Buchanan, 1981). Mean monthly streamflows measured at the Niobrara River near Sparks, Nebr. (USGS site 06461500), have decreased in all months except January, with the largest decreases taking place during June ( 9.5 percent), July (24.4 percent), August (25 percent), September (24.7 percent), and October (24.7 percent) (Istanbulluoglu, 2008). The 1-day low flow and 14-day low flow measured at the Niobrara River at Mariaville, Nebr. (USGS site 06463720 [discontinued in 1991, reinstated in 2012]) decreased by 162 cubic feet per second $\left(\mathrm{ft}^{3} / \mathrm{s}\right)$ and $200 \mathrm{ft}^{3} / \mathrm{s}$, respectively (Fischer, 1987). These changes in hydrology led to channel narrowing processes such as island formation and attachment of islands to the flood plain (Buchanan, 1994).

\section{Recent Climatic Variability}

The north-central region of Nebraska that encompasses the study area had abnormally wet and dry periods before and after the Niobrara River's designation as a National Scenic River in 1991. Climatic indices such as the Palmer Drought Severity Index (PDSI) provide a quantitative method for comparing climate conditions during different time periods. The PDSI quantifies climatic conditions by comparing moisture supply and demand to calculate a "moisture anomaly" index that expresses the relative departure of weather conditions from historical average moisture conditions (Palmer, 1965; Alley, 1984). The National Oceanic and Atmospheric Administration (NOAA) calculates PDSI as a monthly time series using monthly precipitation and temperature data along with their historically near-normal conditions (Palmer, 1965). The PDSI values for the north-central region of Nebraska were obtained from NOAA's National Climatic Data Center (National Oceanic and Atmospheric Administration, 2014). In 1988, the region had a wet period (PDSI greater than 1 for a majority of the year) followed by a dry period (PDSI less than -1 for a majority of the year) during 1989-91 (fig. 2). During 1990, the driest year during the study period, average monthly PDSI was -2.84 . Immediately after the National Scenic River designation in 1991, the north-central Nebraska region had an extended wet period (1992-99), followed by a dry year in 2000, a wet year in 2001, and a dry 3-year period during 2002-4. This 3-year dry period (average monthly PDSI value of -2.23) was similar to the dry period during 1989-91 (average monthly PDSI value of -2.26). Near-normal climatic conditions followed until 2007 when a 4-year wet period extended through 2010 (fig. 2). During 2010, the wettest year during the study period, average monthly PDSI was +6.66 .

\section{Methods}

The purpose of the study described in this report was to develop an understanding of how changes in streamflow affect stream-channel morphology in the Niobrara National Scenic River. The study focused on a time period prior to designation of the Niobrara National Scenic River through 2010. The study used a three-stage approach: (1) analysis of hydrologic variability, (2) quantification of channel morphology over time, and (3) development of basic statistical relations between measures of channel morphology and hydrology. Aerial imagery was available for 1993, 1999, 2003, 2006, and 2010; therefore, the analyzed time periods were 1988-93, 1994-99, 2000-3, 2004-6, and 2007-10.

\section{Streamflow}

Streamflow data were downloaded from the USGS National Water Information System (NWIS) (U.S. Geological Survey, 2015) web service. Daily mean streamflow and annual peak discharge values were downloaded for three streamgages located in the vicinity of the study area: Niobrara River near Sparks, Nebr. (USGS site 06461500); Long Pine Creek near Riverview, Nebr. (USGS site 06463500); and Plum Creek at Meadville, Nebr. (USGS site 06462500). These sites will hereinafter be called Niobrara River near Sparks, Long Pine Creek near Riverview, and Plum Creek at Meadville, respectively.

Flood-frequency curves provide critical information for historical hydrologic analysis and water resources planning (Dunne and Leopold, 1978). Although the focus of this report is on low flows, a simple statistical analysis of flood-frequency curves was used to establish a typical bankfull discharge, which is an important benchmark for determining how well a river maintains its channel's average state (Leopold, 1994). Peak flows after Merritt Dam began operating in 1964, hereinafter referred to as "post-regulation," were used to estimate the bankfull discharge for the Niobrara River near Sparks. Discharge was associated with the 1.5-year (or 0.6667 annual occurrence probability) recurrence interval flood, which is widely considered a reasonable estimate of bankfull discharge (Leopold, 1994; Hortness and Berenbrock, 2004) when only 


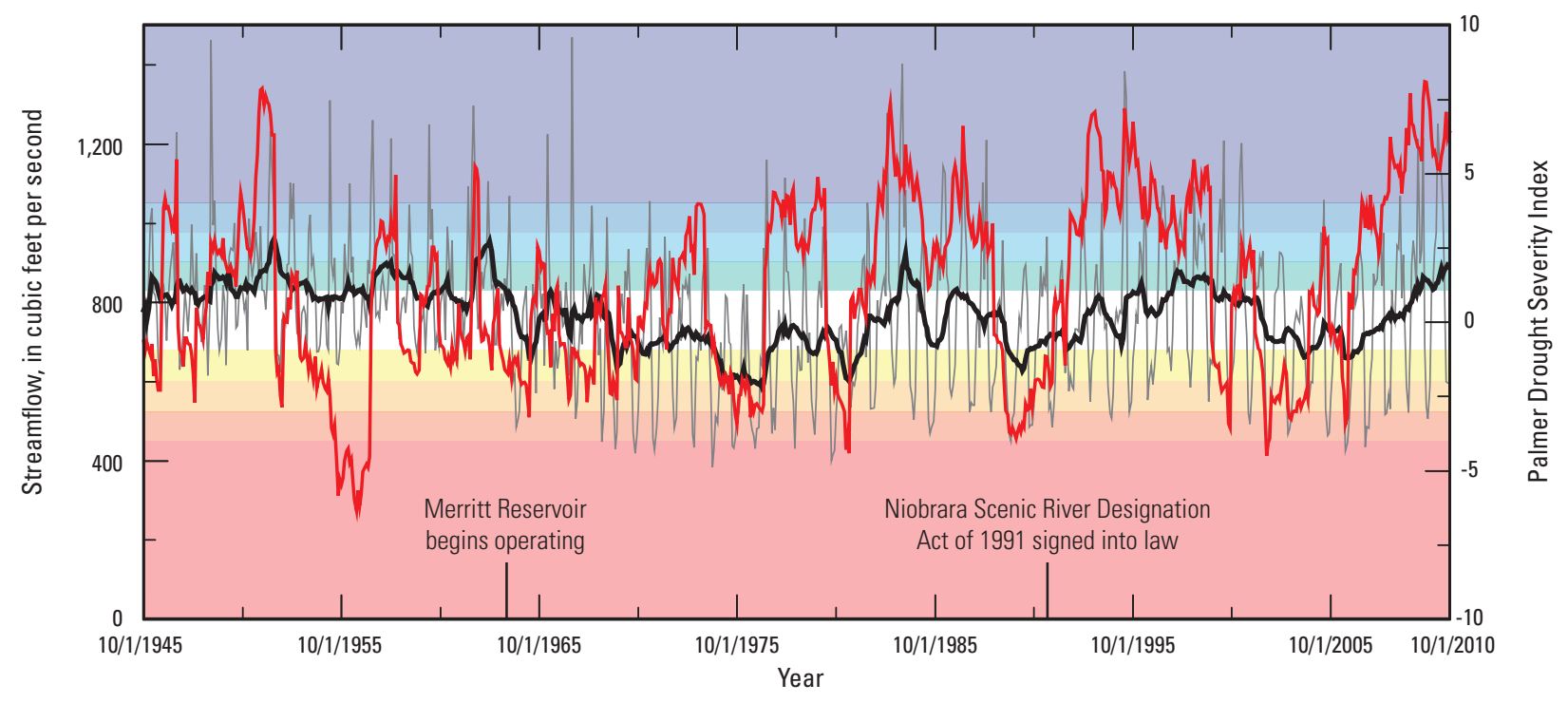

EXPLANATION

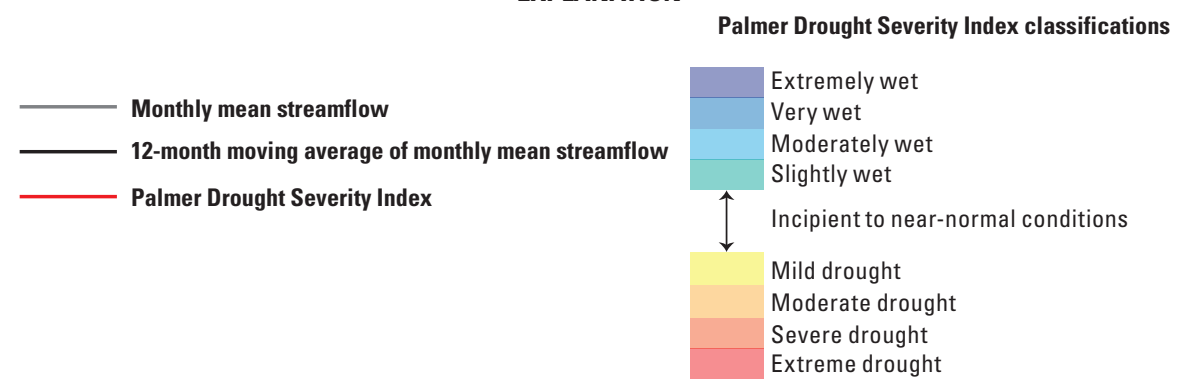

Figure 2. Summary of monthly mean streamflow of Niobrara River near Sparks, Nebraska (U.S. Geological Survey site 06461500), and Palmer Drought Severity Index (National Oceanic and Atmospheric Administration, 2014) for north-central region of Nebraska, water years 1946-2010.

limited observations of channel hydraulics are available. The 1.5-year flood for the river segment used for this study was estimated using the USGS computer program, PeakFQ (Veilleux and others, 2014), and the annual instantaneous peak-flow values for the Niobrara River near Sparks. Only the values after 1964 were used to estimate the 1.5 -year flood. Analysis was done for a period of regulated streamflow, so the station skew option was selected based on recommendations in "Guidelines for determining flood frequency" (Interagency Advisory Committee on Water Data, 1982). The discharge associated with the1.5-year flood for the post-regulation period was $1,829 \mathrm{ft}^{3} / \mathrm{s}$ and is consistent with Alexander and others (2010), who determined that the flood plain in the canyon section of the river upstream from the study area was inundated by a discharge between 1,530 and $2,150 \mathrm{ft}^{3} / \mathrm{s}$. Peak flows at Niobrara River near Sparks were compiled for 1988-2010 (years shortly preceding and following the Niobrara National Scenic River Designation Act of 1991) and compared to the 1.5-year flood.

The statistical likelihood of daily and monthly streamflows within the study area was characterized using flowduration curves. Flow-duration curves indicate how likely it is that a particular streamflow magnitude will take place during a particular period (Krstolic and Ramey, 2012) and represent cumulative percentiles of streamflow. Flow-duration curves were calculated using USGS tools within the TIBCO Spotfire S+® software package (S+; TIBCO Software, Inc., 2008).

Flow-duration curves using daily streamflow values were developed for three USGS streamgages: Niobrara River near Sparks, Plum Creek at Meadville, and Long Pine Creek near Riverview. Flow-duration curves were computed by month for all streamgages. Monthly flow-duration curves were computed using all years within the study period (1988-2010), as well as for each of the individual time periods (1988-93, 1994-99, 2000-3, 2004-6, and 2007-10) for the USGS streamgages Niobrara River near Sparks and Long Pine Creek near Riverview. The starting year, 1988, was selected on the basis of Istanbulluoglu's (2008) determination that the Niobrara River streamflow may be influenced by precipitation from as many as 5 previous years. Only daily streamflow from 1988 to 1994 was used for analysis of the Plum Creek at Meadville streamgage because the streamgage was decommissioned at the end of 1994. Median monthly streamflow calculated for Niobrara River near Sparks indicated that for the 1988-2010 study period streamflow was lowest during the 3 months of July, August, and September. 
The late summer months of July, August, and September (hereinafter referred to as "summer") were thus identified as the low-flow season and targeted for further in-depth analysis. The 10th, 25th, 50th, and 75th percentiles were calculated for the low-flow season for Niobrara River near Sparks and Long Pine Creek near Riverview. Low-flow season percentiles and duration curves were not calculated for Plum Creek at Meadville because the streamflow record (1948-94) did not extend throughout the overall study period. For duration curves for July through September, streamflow percentiles were calculated for each year from 1988 to 2010 independently as well as for the entire post-regulation period (1964-2011). The summer low-flow percentiles calculated for the post-regulation period were then compared to each year's summer low-flow percentiles to calculate summer median departures and number of days with streamflow below the 10th percentile of summer low flow, which is a good indicator of the severity of a dry season (Krstolic and others, 2006).

\section{Channel Morphology}

Analysis of aerial photographs was used to identify changes in channel morphology during the study period. Delineations of channel morphologic features were digitized into a geographic information system (GIS). Feature layers were registered to rectified and georeferenced digital aerial photographs. Aerial photographs from 1993, 1999, 2003, 2006, and 2010 were selected for analysis (table 1). The 1993 aerial photographs were assumed to best represent the state of the Niobrara River at the time of designation as a National Scenic River. The photographs were taken during periods of varying discharges (table 1). By delineating only identified islands, incipient flood-plain surfaces, and high banks, the authors were able to reduce positional uncertainty caused by imprecision in the exactly coincident discharge for each photograph. To quantify channel alterations spatially and temporally, specific channel metrics were selected for analysis. Channel width, braided index, percentage of cross sections intersected with incipient flood-plain surfaces and islands, and area of incipient flood-plain surfaces and islands were calculated. These geomorphic characteristics were selected because they can be identified during various flow conditions and indicate if the channel is becoming overly vegetated, which reduces bird habitat.

Quantification of channel morphology focused on identifying areas of the channel that were vegetated and non-vegetated, and followed a simplified version of the flood-plain development model described by Reinfelds and Nanson (1993). Channel morphologic features were digitized on-screen into a GIS. Three primary features were digitized in each photograph: (1) top-of-bank along the active channel, (2) top-of-bank for mature islands (defined as being within the channel area bounded by active-channel bank lines and covered with mature shrubs or woodland vegetation) within the active channel, and (3) boundaries of incipient flood-plain surfaces (defined as being within the active channel and covered with small shrubs or herbaceous vegetation, and previously not having vegetation cover) within the active channel. Areas outside the active channel and islands were considered to be established flood plain or terraces and were identified by their generally taller vegetation and visually coarse texture (from vegetation), by comparison with previous aerial photos and by comparison of land-surface height relative to that of adjacent surfaces. The latter comparison was made using a digital elevation model. Incipient flood-plain surfaces within the channel banks were identified as those that (1) were not vegetated in a previous photo, and (2) were lighter in tone and finer in texture than nearby areas of established flood plain in the same photograph. Incipient flood-plain surfaces were considered transitional between active channel and established flood plain. If an incipient flood-plain surface persisted (apparently) by appearing also in the subsequent set of aerial photographs, the incipient flood-plain surface was identified as established flood plain in the subsequent set of aerial photographs.

Morphologic features were identified from each year's aerial photographs using interpretation and analysis by one GIS technician and then were checked and edited by a geomorphologist. Features were digitized at a scale of 1:2,000 to 1:4,000 depending on the resolution and quality of the photograph. Channel and island bank lines were digitized along the tops of banks. Incipient flood-plain surfaces were digitized at the edges of vegetation patches (fig. 3). If a questionable area in one photograph (mainly 1993, which had lesser quality) showed up as vegetated in the subsequent year's photograph, then the photograph in question was assumed to also be vegetated. A 2-m digital elevation model obtained from light detection and ranging (lidar) data from 2012 overflights (Merrick and Co., 2012) was used to help differentiate between incipient flood-plain surfaces and established flood plain in the 2010 aerial photographs. The established floodplain was generally at least $0.2 \mathrm{~m}$ higher than the incipient flood-plain surfaces. Channel centerlines were created for each year to provide a longitudinal stationing system. Centerlines were developed using the Channel Planform Statistics Toolbox (Lauer, 2006). The tool was used to create centerline vertices at 30-m longitudinal intervals, approximately a one-tenth average channel-width spacing. Cross sections were also created at each 30-m longitudinal interval (fig. 3) and used to calculate the following river-channel metrics: (1) channel width, (2) channel braided index, and (3) percent of channel width intersecting established islands and incipient flood-plain surfaces. Results of GIS analysis were summarized by study segment. The study segments are described in the "Description of Study Area" section.

Channel width. - Channel width was analyzed using two separate classifications: total channel width, which excludes islands, and active channel width, which excludes islands and incipient flood-plain surfaces. Cross sections were truncated ("clipped") at the boundaries of the channel (banklines) and then the digitized islands were clipped from the subsequent 
Table 1. Characteristics of aerial photography used for calculating channel metrics, eastern Niobrara National Scenic River, 19932010.

[RMSD, root-mean-square difference; 2003 aerial photographs used as reference for registration error calculations. Streamflows are mean daily streamflows for U.S. Geological Survey streamgage Niobrara River near Sparks, Nebraska; uncertainty of positions compared between photography years assumes independent registration errors; --, not applicable]

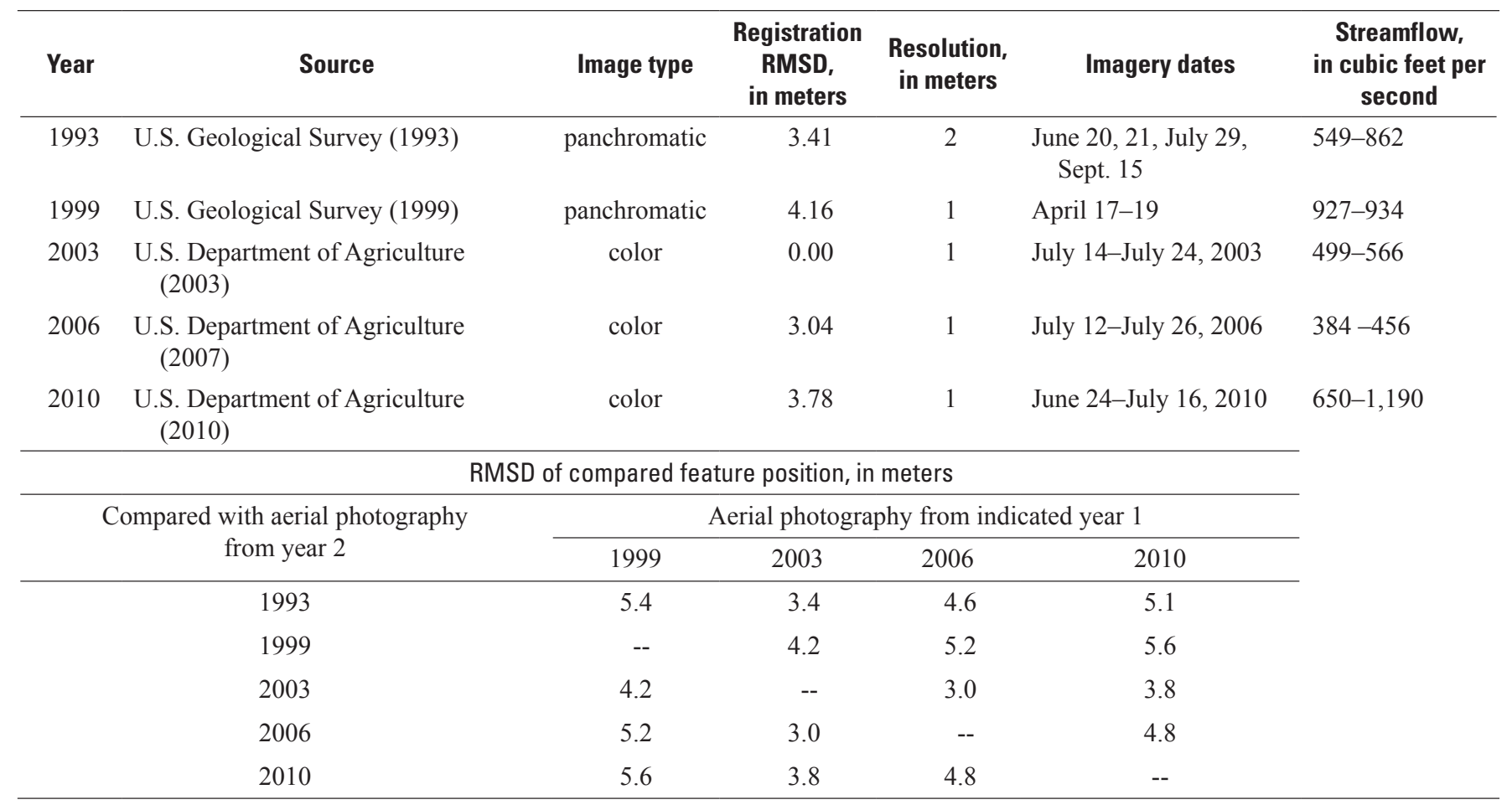

line features to provide measures of total channel width. Lastly, the digitized incipient flood-plain surfaces were clipped from the total width line features to obtain active channel width.

Braided index.-Braided index was calculated for each study segment by summing the total number of line segments that resulted from splitting the cross sections using mature island and incipient flood-plain surfaces, and dividing that number by the total number of cross sections in the study segment. This method of calculating braided index differs from that used by some previous investigators (for example, Elliott and Jacobson, 2006) who included sandbars as well as islands when computing a braided index. The quality of many photographs used for this study did not allow analysts to confidently distinguish between wetted and non-wetted sandbars; therefore, a braided index summing the number of channels between incipient flood-plain surfaces and islands was used herein.

Measures of island and incipient flood-plain extent.-The percent of cross sections intersecting islands and incipient flood-plain surfaces was calculated within each segment as well as the area of these surfaces per river kilometer. The number of cross sections split by each of incipient flood-plain surfaces and islands was summed and then divided by the total number of cross sections to determine the percentage of cross sections within a study segment that intersected incipient flood-plain surfaces or islands. The area of islands and incipient flood-plain surfaces was summed for each segment. Areas of incipient flood-plain surfaces and islands were then divided by the segment length to obtain the segment-mean area of incipient flood-plain surfaces and islands per kilometer.

Additionally, total channel width and active channel width were analyzed using the 1993 centerline for all photography years, which allowed comparison of site-specific changes between years, analogous to paired samples. The paired comparison assisted in identification of specific reaches that had large geomorphic changes and the associated geomorphic processes that likely caused the changes.

\section{Quantification of Uncertainty}

Uncertainty in the classification process was quantified to determine if measured differences were real or within the range of error and therefore negligible. Various quantifications of classification accuracy and error were estimated. The root-mean-square difference (RMSD) was used to quantify differences between identical geolocations shown in different photographs, which is important when comparing colocated cross sections. Precision of the classification process also was estimated and the associated areal uncertainty was quantified. These two uncertainty metrics are pertinent to 


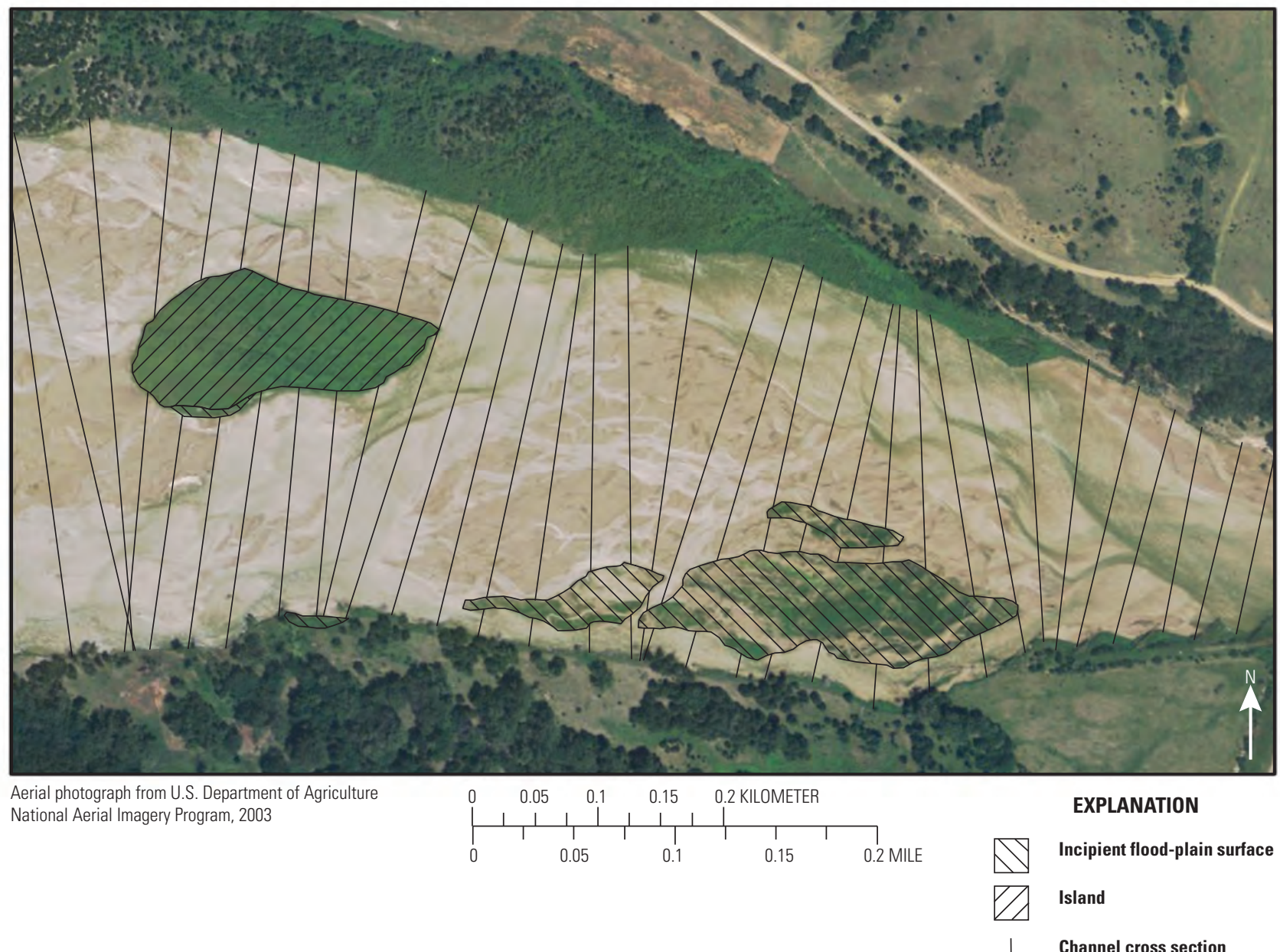

Figure 3. Digitized features on 2003 aerial photograph of example segment of eastern Niobrara National Scenic River, in northcentral Nebraska.

all segment-scale gross calculations (average width, braided index, and vegetated area summations).

$R M S D$.- Horizontal positional difference between photography years was determined for each set of aerial photographs by calculating the RMSD of co-located groundreference points (roof corners, building edges, fence corners) that were matched to the reference base map. The 2003 imagery was used to identify original reference points because these photographs had a combination of high spatial resolution and natural color that improved edge detection and contrast (table 1). For each photography year, reference points were located at a spacing of 3 river kilometers or less (measured longitudinally along the river centerline), which resulted in at least 27 points for each photography year. These reference points were used to calculate the RMSD where:

$$
R M S D=\sqrt{\frac{\sum_{a}^{n}\left(\left|P(x)_{a}-p(x)_{a}\right|+\left|P(y)_{a}-p(y)_{a}\right|\right)^{2}}{n}}
$$

where

$R M S D \quad$ is root-mean-square difference in horizontal position between the co-located points of the target photography year and 2003 (basemap reference),

$P(x)_{a} \quad$ is the location in the $x$ direction of point $a$ in the 2003 aerial photographs,

$p(x)_{a} \quad$ is the location in the $x$ direction of point $a$ in the target year's aerial photographs,

$P(y)_{a} \quad$ is the location in the $y$ direction of point $a$ in the 2003 aerial photographs,

$p(y)_{a} \quad$ is the location in the $y$ direction of point $a$ in the target year's aerial photographs, and

$n \quad$ is the total number of co-located points.

Spatial errors are inherent in the rectification process of aerial photographs, so the RMSD is used to assess and, if rectification can be repeated, to subsequently minimize these errors. The RMSD quantifies the minimum detectable change of co-located channel morphologic features between years. For instance, in the case of a 3-m RMSD, the channel cross section being analyzed could be mislocated (relative to another 
photo) on the photograph $3 \mathrm{~m}$ upstream or downstream from where the cross section appears to be located on another year's photograph. RMSD results for this study ranged from 3.04 to $4.16 \mathrm{~m}$ by year of aerial photography and from 3.0 to $5.6 \mathrm{~m}$ for year-to-year aerial photography feature comparisons (table 1).

Classification accuracy.-Errors of commission or omission caused by assigning areal units to categories are often tabulated for a sample of "ground truth" points, and the resulting contingency table may be analyzed to quantify the classification accuracy. Because historical photographs were analyzed for this study, ground truthing generally was not possible, so classification accuracy was not estimated.

Classification and areal uncertainty.-Classification uncertainty was estimated by summing the resolution of the aerial photographs with an estimate of feature boundary identification uncertainty. The horizontal resolution of aerial photographs varied from 1 to $2 \mathrm{~m}$ depending on the year (table 1). An additional error of as much as $3 \mathrm{~m}$ was estimated to correspond to feature-boundary uncertainty experienced during the classification process as a result of poor clarity in some of the photographs. Based on these factors, the horizontal uncertainty of the banklines, island boundaries, and incipient flood-plain surface boundaries are estimated at as much as $4 \mathrm{~m}$ for sets of aerial photographs with 1-m resolution $(1999,2003,2006$, and 2010) and as much as $5 \mathrm{~m}$ for aerial photographs with 2-m resolution (1993). This means that any detectable changes in width between 1993 and 1999 of less than $5 \mathrm{~m}$ and less than $4 \mathrm{~m}$ between subsequent periods are negligible. Following the reasoning and methodology of Dunn and others (1990), the average discrepancy in the classification of a particular feature by the same technician was estimated based on two assumptions: the range of delineation errors, assumed to be $5 \mathrm{~m}$ on either side of the actual boundary; and the frequency distribution of errors, assumed to follow a beta distribution with shape parameter 9. The median width, $w$, of the uncertainty band along delineations was estimated as the average interquartile range of discrepancies from a Monte Carlo simulation (Fishman, 1995) of 1,000 repetitions, or $2.24 \mathrm{~m}$. Consequently, the areal uncertainty of delineated map units was then estimated as the mean polygon perimeter length multiplied by $w$ along the perimeter. The average areal uncertainties of each type of in-channel feature are presented in table 2 . These areal uncertainties apply to the calculated areas of islands and incipient flood-plain surfaces. Expressed as percentages of the feature classes' average area by segment during the study period, uncertainties were no more than 18.7 percent for incipient flood-plain area, and no more than 47.5 percent for island area (table 2). Because the errors are dependent on the size of feature, error as a percentage of average feature area was higher in segments with features that had higher perimeter to area ratios. For example in segments 2 and 3 the islands were wider so the percentage of error was no greater than 10.6 percent (table 2). Conversely in segment 1 for 2003 there was only one narrow island and so the percentage of error was 47.5 percent (table 2).

\section{Effects of Streamflows on Stream- Channel Morphology}

\section{Streamflow}

In this section, results of the hydrologic analysis are presented and compared among the five analyzed time periodsfirst for peak flows, then for monthly flows for all seasons, and lastly two subsections focus on streamflow during the summer season only. The first summer subsection is focused on summer low flows in the Niobrara River, whereas the second addresses summer low flows in Long Pine Creek.

\section{Peak Flows}

Maximum instantaneous peak flows at Niobrara River near Sparks during the first two study periods were generally higher than those during the latter three periods (fig. 4). The largest peak was in 1994 and the smallest peak was in 2004 (fig. 4). The large peak in 1994 was an estimated value $\left(4,800 \mathrm{ft}^{3} / \mathrm{s}\right)$ and was at a stage higher $(2.74 \mathrm{~m})$ than what is usually expected for that magnitude of streamflow, because of backwater from ice breakup. For comparison, peak-flow stages unaffected by backwater ranged from 0.94 to $1.51 \mathrm{~m}$ during the study period.

Peak flows were expressed as departure from estimated bankfull discharge (fig. 4), because bankfull discharge can be an important factor in determining how well the river maintains the average state of the channel (Leopold, 1994). The calculated 1.5 year flood $\left(1,834 \mathrm{ft}^{3} / \mathrm{s}\right)$ was used as the estimated bankfull discharge. There were 2 years during the analysis period of 1988-93 (water years 1989 and 1990) with peak discharges more than 50 percent greater than the bankfull discharge (fig. 4). For the remainder of the study period, there were only 2 years (water years 1994 and 2001) with a peak discharge more than 50 percent greater than the bankfull discharge (fig. 4).

The longest duration of time without a peak flow greater than the bankfull discharge was 3 years. This happened three times during the study period (1991-93, 1997-99, and 2002-4), illustrating again how typical this duration is of dry spells in the basin. Of the five analysis time periods, 2004-6 had the smallest peak flows with an average peak flow 22.4 percent below the bankfull discharge. Of the study years in which aerial photographs were analyzed, only 2006 and 2010 had peak flows greater than bankfull discharge either during the year of the photography or in the antecedent year.

\section{Seasonal Distribution of Monthly Flows}

Monthly flow-duration curves calculated for the study period indicated that the three lowest months for streamflow at Niobrara River near Sparks were July through September (fig $5 A$ ). Monthly median streamflows decreased by about 
Table 2. Average areal uncertainty of digitized features in the eastern Niobrara National Scenic River, Nebraska, $1993-2010$.

[NA, not applicable]

\begin{tabular}{|c|c|c|c|c|}
\hline \multirow[b]{2}{*}{ Year } & \multicolumn{4}{|c|}{ Average areal uncertainty of indicated feature class } \\
\hline & $\begin{array}{l}\text { Incipient flood plain, } \\
\text { in square meters }\end{array}$ & $\begin{array}{c}\text { Island, } \\
\text { in square meters }\end{array}$ & $\begin{array}{c}\text { Incipient flood plain, } \\
\text { in percentage of indicated } \\
\text { feature classes' average area } \\
\text { during study period }\end{array}$ & $\begin{array}{c}\text { Island, } \\
\text { in percentage of indicated } \\
\text { feature classes' average area } \\
\text { during study period }\end{array}$ \\
\hline \multicolumn{5}{|c|}{ Segment 1} \\
\hline 1993 & 1,046 & 634 & 17.2 & 19.1 \\
\hline 1999 & 1,178 & 475 & 13.4 & 17.7 \\
\hline 2003 & 983 & 220 & 18.7 & 47.5 \\
\hline 2006 & 1,306 & 0 & 15.7 & NA \\
\hline 2010 & 1,116 & 1,064 & 14.6 & 11.8 \\
\hline \multicolumn{5}{|c|}{ Segment 2} \\
\hline 1993 & 956 & 1,328 & 15.2 & 7.9 \\
\hline 1999 & 1,270 & 1,230 & 9.1 & 8.1 \\
\hline 2003 & 914 & 844 & 16.1 & 10.6 \\
\hline 2006 & 1,295 & 811 & 13.3 & 10.5 \\
\hline 2010 & 934 & 840 & 14.3 & 10.6 \\
\hline \multicolumn{5}{|c|}{ Segment 3} \\
\hline 1993 & 986 & 1,378 & 15.6 & 6.2 \\
\hline 1999 & 871 & 2,092 & 17.6 & 5.0 \\
\hline 2003 & 916 & 1,651 & 14.2 & 6.0 \\
\hline 2006 & 1,297 & 1,900 & 14.4 & 5.9 \\
\hline 2010 & 948 & 2,256 & 14.7 & 6.2 \\
\hline
\end{tabular}

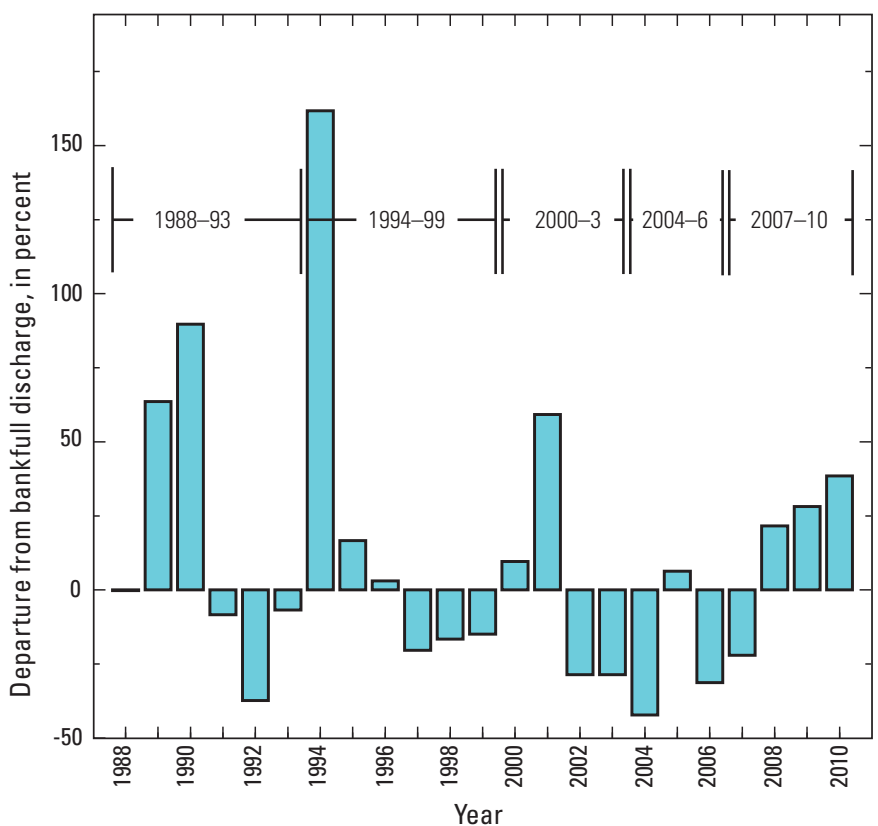

Figure 4. Annual series of peak flows for Niobrara River near Sparks, Nebraska, 1988-2010. Peak-flow values are reported as a percentage departure from the bankfull discharge, which was estimated using the 1.5-year flood discharge. 

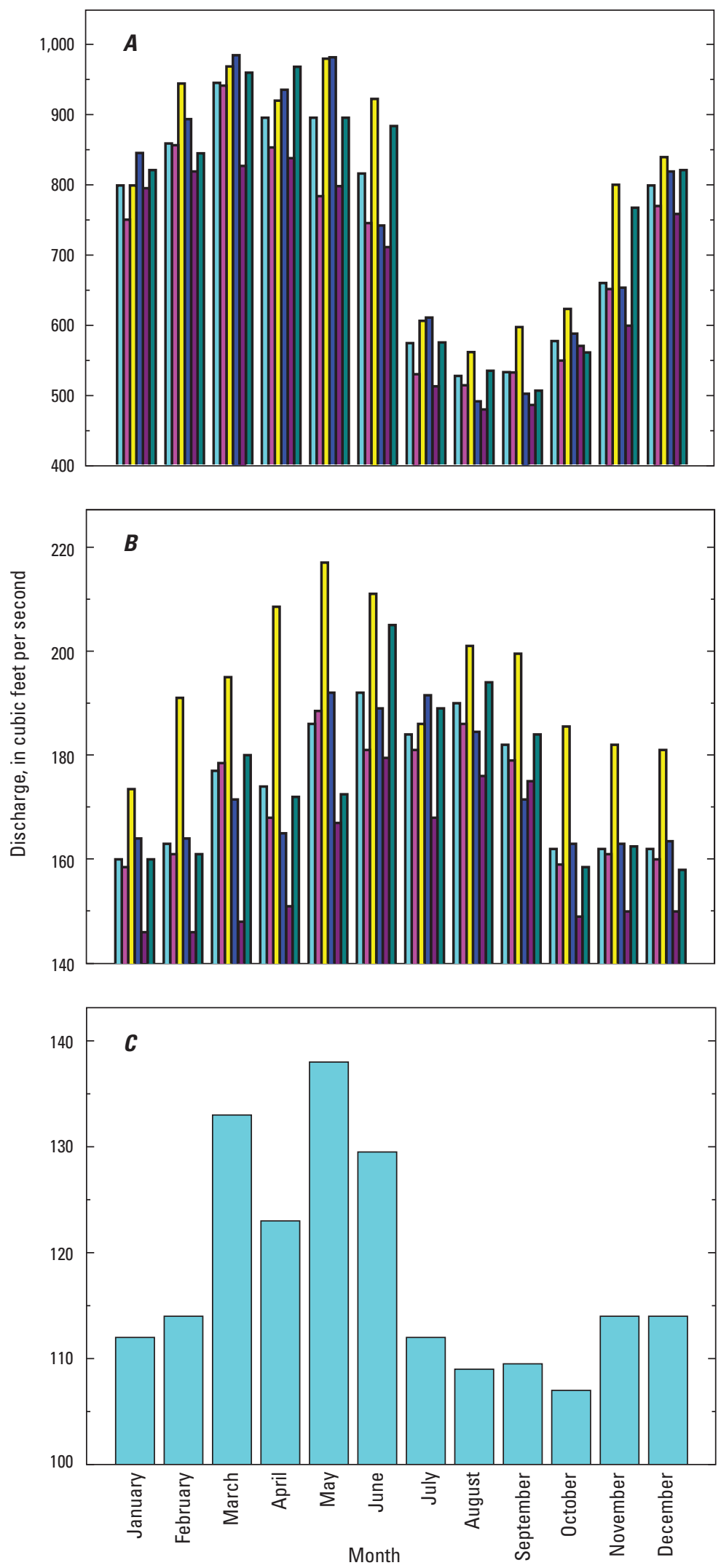

EXPLANATION

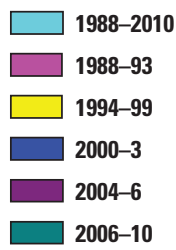

Figure 5. Median monthly streamflows for selected streamgages near the study area. $A$, Niobrara River near Sparks (USGS site 06461500), 1988-2010; $B$, Long Pine Creek near Riverview (USGS site 06463500), 1988-2010; and $C$, Plum Creek at Meadville, Nebraska (USGS site 06462500), 1988-94. 
$200 \mathrm{ft}^{3} / \mathrm{s}$ from June to July in most years. By October, streamflows begin to rebound, coincident with the end of irrigation season, but autumn (October through November) streamflows remain lower than those in winter (December through February) and spring (March through May). Median monthly streamflows were highest during the 1994-99 period for 7 of the 12 months (fig. 5A). The 2004-6 period was the only period with July, August, and September median-monthly streamflows all below those for 1988-2010. The 2004-6 period also had the two lowest median monthly streamflows, which were in August and September $\left(479 \mathrm{ft}^{3} / \mathrm{s}\right.$ and $486 \mathrm{ft}^{3} / \mathrm{s}$, respectively). The 1994-99 period had the highest median monthly streamflows for all summer months except July where it had the second highest.

By contrast, median monthly streamflow for Long Pine Creek indicates a seasonal pattern driven by irrigation return flows during May through September. From 1988 to 2010, Long Pine Creek median monthly streamflows were consistent, differing by only 20 percent, between driest (January) and wettest (June) months (160 ft $3 / \mathrm{s}$ to $192 \mathrm{ft}^{3} / \mathrm{s}$, respectively) (fig. 5B). Similar to Niobrara River near Sparks, the period from 1994 to 1999 generally had the highest median monthly streamflows. The 2004-6 period had lowest median streamflows in all months except September.

Plum Creek is less consistent than Long Pine Creek and lacks the signature of return flows during the irrigation period. Only March through June had median streamflows greater than $120 \mathrm{ft}^{3} / \mathrm{s}$. The highest monthly flows correspond to snowmelt (typically March) and spring rains on the Great Plains. Median flows for the remaining 8 months reflect steady base flow and differed by only $7 \mathrm{ft}^{3} / \mathrm{s}$ (fig. 5C). The streamgage Plum Creek at Meadville was discontinued in 1994; therefore, comparison of the three analysis periods was not possible.

\section{Summer Low Flows of Niobrara River}

Summer low-flow analysis for Niobrara River near Sparks indicated that of the five analysis periods, 2000-3 and 2004-6 had the most extended periods of low streamflow (fig 6A). In both periods, 25 percent of flows were below $500 \mathrm{ft}^{3} / \mathrm{s}$ for all years but one (fig. 6A). During the 1988-93 period, 3 of the 6 years had similarly low summer streamflow and the 2007-10 period began with 2 low-flow years as well. The 1994-99 period had no years with similarly low streamflow.

The wetter period from 1994 to 1999 ended with 3 wet years, each with a 50th (median) percentile of summer streamflow greater than $600 \mathrm{ft}^{3} / \mathrm{s}$. In contrast, the 1988-93 period had only 1 year (1993) with a median summer streamflow greater than $600 \mathrm{ft}^{3} / \mathrm{s}$, and no years following 1999 had a median summer streamflow greater than $600 \mathrm{ft}^{3} / \mathrm{s}$. The lowest median summer streamflow $\left(442 \mathrm{ft}^{3} / \mathrm{s}\right)$ occurred in 2002 , whereas the largest median summer streamflow $\left(653 \mathrm{ft}^{3} / \mathrm{s}\right)$ occurred during 1997 (fig. 6A).

Median summer streamflow was more than 10 percent less than the post-regulation period median summer streamflow $\left(526 \mathrm{ft}^{3} / \mathrm{s}\right)$ during 4 years $(2002,2005-7)$ in the $2000 \mathrm{~s}$.
Median summer streamflow fell more than 10 percent below the historical median in only 1 year (1989) during 1988-93, and no years during 1994-99 (fig. 6B). The annual series of departures from the long-term median also show that departures of greater than 7 percent generally lasted from 2 to 4 years.

During the study period, several years had extended periods of extremely low flow (extremely low flow defined hereinafter as daily mean streamflow below the 10th percentile of post-regulation summer flows) (fig. 6C). During the 2004-6 period, 2 years (2005 and 2006) had 10 or more summer days of extremely low flow (fig. 6C). Three other periods (1988-93, 2000-3, and 2007-10) had 1 year with more than 10 days of extremely low flow. Two extremely dry years (2002 and 2006) had more than 30 summer days with extremely low streamflow (fig. 6C). During 2002, there were three events of at least 7 consecutive days with streamflow below the 10th percentile. Two of these events were only separated by 1 day of respite, which prevented the low-flow event from lasting 21 consecutive days; instead, it was a 7-day low-flow event followed by a 13-day low-flow event. During 2006, there was a 27-day low-flow event, which was the longest low-flow event during the study period.

\section{Summer Flows of Long Pine Creek}

Summer flows of Long Pine Creek generally were higher than flows during the remainder of the year (fig. $5 B$ ), a pattern that contrasted with that of summer low flows of the Niobrara River. The summer flows of Long Pine Creek provided a substantial source of summer streamflow to the Niobrara River. Median summer streamflow of Long Pine Creek near Riverview was $170 \mathrm{ft}^{3} / \mathrm{s}$ during the post-regulation period, which is about 30 percent of total summer median streamflow of the Niobrara River near Sparks.

Similar to the Niobrara River near Sparks summer streamflows, the summer streamflows at Long Pine Creek were highest during the 1994-99 study time period (fig. 7A-B) when the average 50th percentile of summer streamflow was $200 \mathrm{ft}^{3} / \mathrm{s}$. The 1988-93, 2000-3, and 2004-6 time periods had the lowest summer streamflows, with each period having multiple years with median summer streamflow less than $180 \mathrm{ft}^{3} / \mathrm{s}$.

Only 3 years $(1989,2002$, and 2006) had summer median streamflow less than the post-regulation median summer flow (fig. 7B). All these years corresponded to years in which summer median streamflow at Niobrara River near Sparks was below the post-regulation median summer flow. Although these years had summer median flows below the post-regulation period median, none of these departures exceeded 8 percent (fig. $7 B$ ).

The annual 10th percentile of summer streamflows and overall 10th percentile of summer streamflows were higher during the study period (1988-2010) than the long-term (1943-2011) 10th percentile of summer streamflows (fig. 7C). Even the lowest 10th percentile of summer streamflows during the study period was not substantially lower than the median 

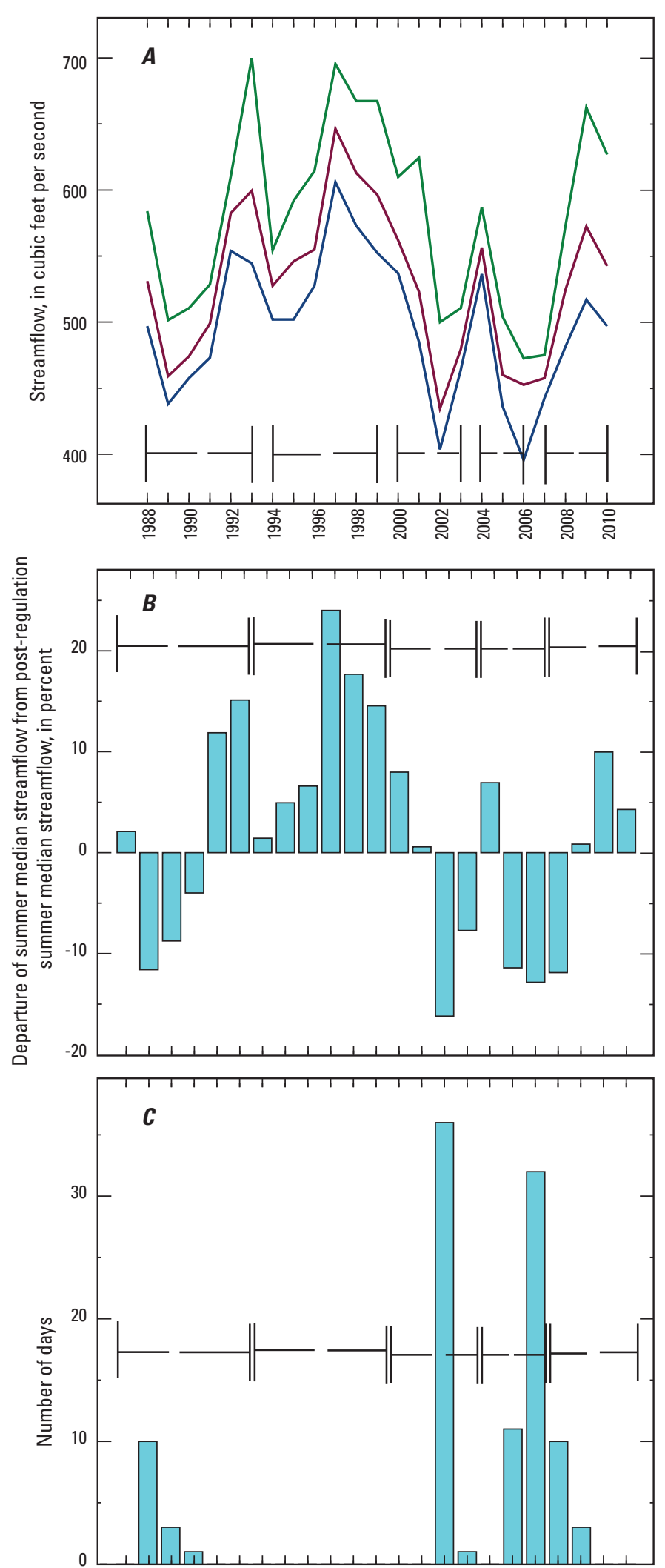

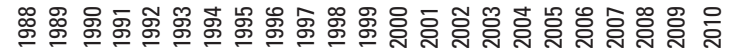

EXPLANATION

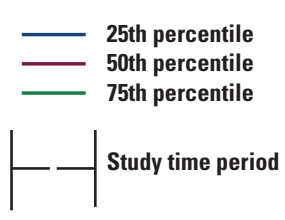

Figure 6. Annual measures of streamflow of Niobrara River near Sparks, Nebraska, 1988-2010. $A$, summer (July through September) flow-duration statistics; $B$, departures of summer median streamflow from post-regulation (1964-2010) summer median streamflow (post-regulation period is after storage began at Merritt Dam); and $C$, number of very-low-flow summer days (that is, daily mean streamflow below the 10th percentile of summer low flow). 


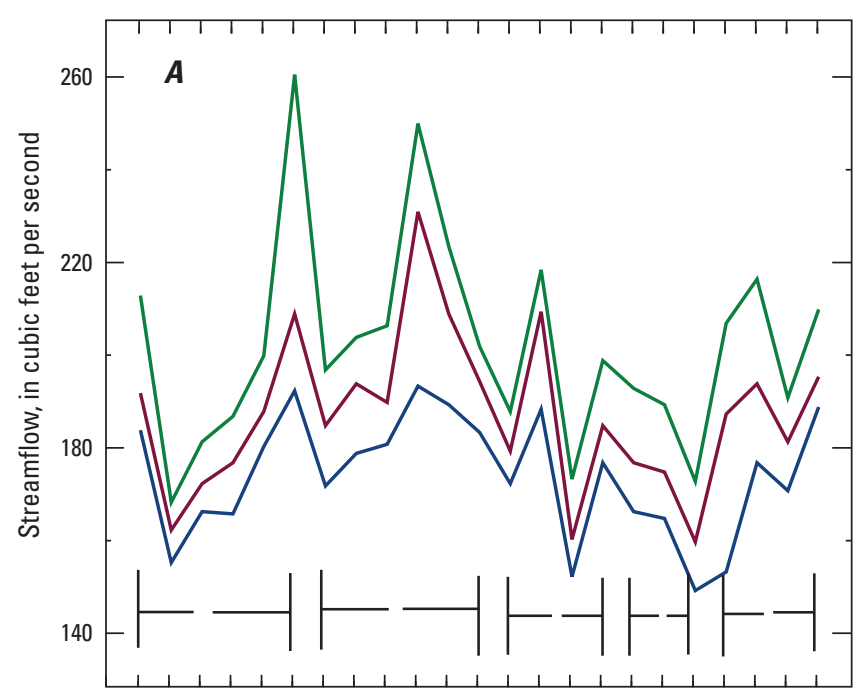

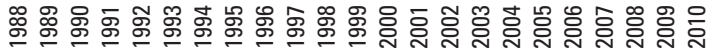
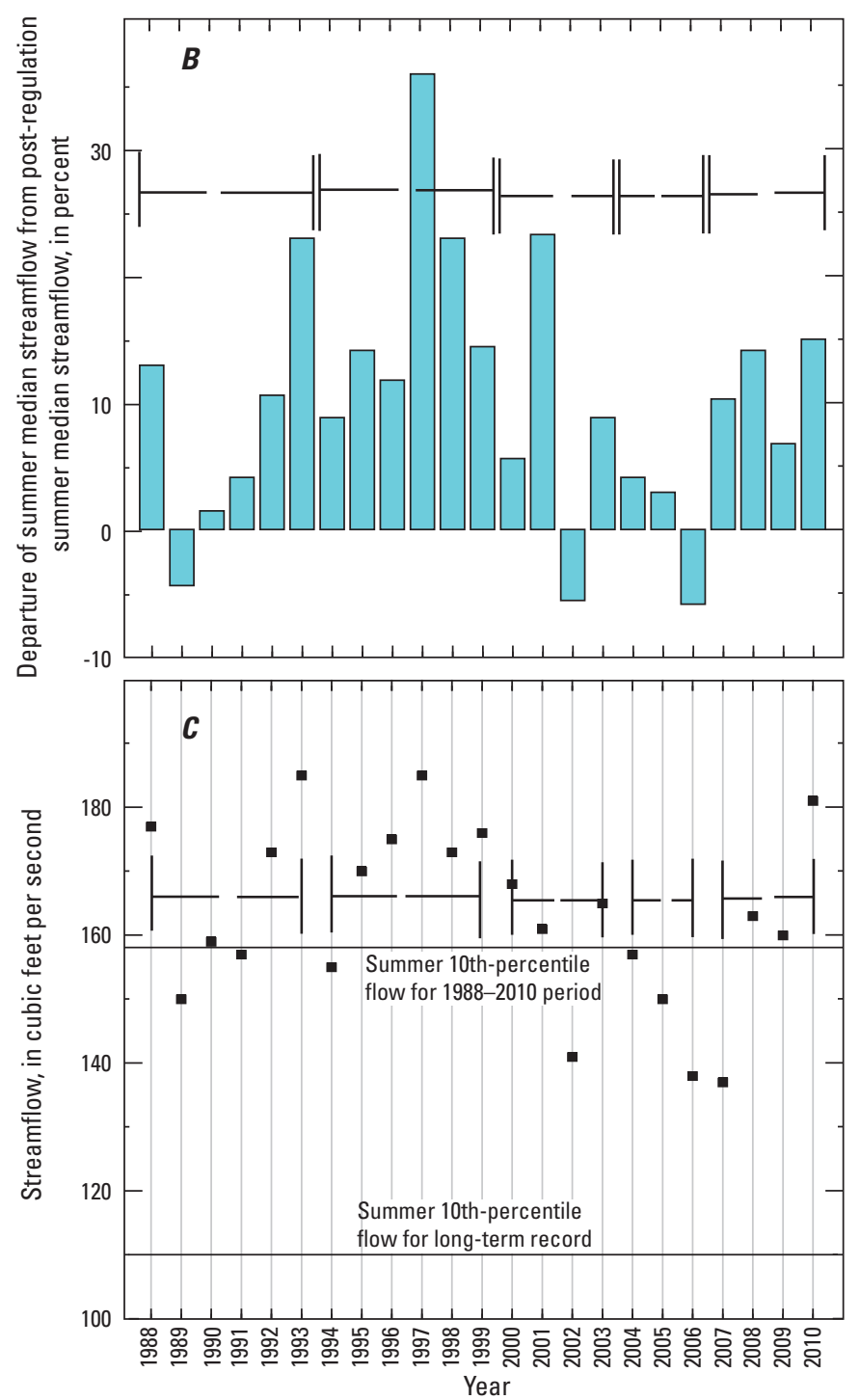

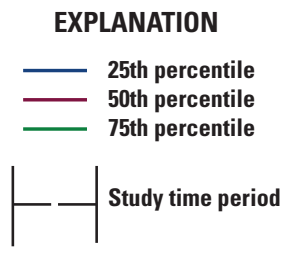

EXPLANATION

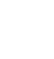


summer streamflow $\left(161 \mathrm{ft}^{3} / \mathrm{s}\right)$ for the long-term record. The 10th percentile of summer streamflows was about $140 \mathrm{ft}^{3} / \mathrm{s}$ during the lowest years (fig. 7C), which is only $30 \mathrm{ft}^{3} / \mathrm{s}$ less than the post-regulation period median summer streamflow. This $30-\mathrm{ft}^{3} / \mathrm{s}$ decrease equates to 6 percent of the median summer streamflow of the Niobrara River near Sparks; therefore, the difference of a low-flow summer from an average summer flow in Long Pine Creek might be barely measureable after its confluence with the Niobrara River, given the typical plus or minus 5-percent uncertainty in a discharge measurement there.

\section{Channel Morphology}

Channel morphologic changes were measured and analyzed for the five analysis periods. The results for channel morphology are presented as segment-level measures of channel change and multitemporal comparisons of selected morphometry at fixed-location cross sections. A discussion of these changes as they relate to the hydrologic and climatic conditions of the five analysis periods (1988-93, 1994-99, 2000-3, 2004-6, 2007-10) is included in the "Effects of Streamflows on Stream-Channel Morphology Changes" section.

\section{Channel Metrics}

Measures of channel morphology indicate that channels changed substantially between 1993 and 1999, and then reversed much of this change between 1999 and 2003. There were generally increases in all measures of channel width between 1993 and 1999 and decreases between 1999 and 2003, but the magnitude of these changes differed by river segment. The largest channel changes among these years were measured in river segments 2 and 3 (fig. 1).

\section{Statistical Comparisons}

The Kruskal-Wallis test was used to determine if there were statistical differences in active channel width for each segment between photography years. The Kruskal-Wallis rank sum test identifies whether or not the distributions of multiple sample sets are identical or different (Helsel and Hirsch, 2002). The active channel width was tested as an overall indication because of its sensitivity to changes in all other geomorphic features (channel boundary, islands, and incipient flood-plain surfaces). At the 90 -percent confidence level ( $p$-value $<0.1$ ), tests for segments 2 and 3 rejected the null hypothesis that the multitemporal measurements originated from the same frequency distribution (table 3 ). At the 95-percent confidence level ( $p$-value $<0.05$ ), only segment 2 rejected the null hypothesis (table 3 ). This indicates that average active channel width varied the most in segment 2 .

Further evaluation was done using Wilcoxon ranksum tests to compare active channel width in sequential photography years for segments 2 and 3 . Since there were no statistically significant differences in the distribution of
Table 3. Statistical analysis test results of measured active channel width between 1993 and 2010 for three segments of the eastern Niobrara National Scenic River.

[df, degrees of freedom; $p$-value, probability value; $\mathrm{n} 1$, number of cross sections in first year of period; $\mathrm{n} 2$, number of cross sections in last year of period]

\begin{tabular}{|c|c|c|c|}
\hline \multirow{2}{*}{ Segment } & \multicolumn{3}{|c|}{ Kruskall-Wallis test } \\
\hline & $\begin{array}{c}\text { Number of } \\
\text { cross sections }\end{array}$ & df & $p$-value \\
\hline 1 & 2,919 & 4 & 0.371 \\
\hline 2 & 3,243 & 4 & 0.014 \\
\hline 3 & 4,662 & 4 & 0.092 \\
\hline \multirow{2}{*}{ Period } & \multicolumn{3}{|c|}{ Wilcoxon rank sum test } \\
\hline & n1 & $\mathrm{n} 2$ & $p$-value \\
\hline \multicolumn{4}{|c|}{ Segment 2} \\
\hline 1993-99 & 649 & 649 & 0.743 \\
\hline 1999-2003 & 649 & 649 & 0.031 \\
\hline $2003-6$ & 649 & 648 & 0.585 \\
\hline $2006-10$ & 648 & 648 & 0.542 \\
\hline \multicolumn{4}{|c|}{ Segment 3} \\
\hline 1993-99 & 934 & 930 & 0.01 \\
\hline 1999-2003 & 930 & 933 & 0.436 \\
\hline $2003-6$ & 933 & 933 & 0.723 \\
\hline $2006-10$ & 933 & 932 & 0.782 \\
\hline
\end{tabular}

active channel measurements in segment 1 at the 90-percent confidence level no further analysis was performed for that segment. For segment 2, the 1999-2003 period was the only period that had a statistically significant difference at the 95-percent confidence level (table 3 ). For segment 3 , only the 1993 to 1999 comparison was significantly different at the 95-percent confidence level (table 3).

Segment 1.-Segment 1 is much narrower than segments 2 and 3 , with average active channel width approximately $100 \mathrm{~m}$ less than those of segments 2 and 3. Despite this, segment 1 had more incipient flood-plain area per river kilometer than both segments 2 and 3 (table 4). Average total channel width remained relatively consistent with only one change (2003-6) between study years greater than the estimated error, whereas small (less than 4 percent) changes in average active channel width were measured between 1993 and 1999, 1999 and 2003, and 2006 and 2010 (table 4, fig. 8A). For comparison, the Platte River (not labeled on fig. 1), a Nebraska river that has narrowed due to water development, had channelwidth reductions of about 10-20 percent per decade due to island expansion or attachment and flood-plain expansion (Johnson, 1994); however, during a 17-year interval from 1993 to 2010 , the Niobrara's active channel width narrowed by $7 \mathrm{~m}$ (4 percent) and total channel width widened by $6 \mathrm{~m}$ ( 3 percent). These are considered real changes because they exceed the uncertainty bandwidth, because the classification error 
Table 4. Measures of channel morphology for three segments of the eastern Niobrara National Scenic River, north-central Nebraska, as measured from aerial imagery for selected years, 1993-2010.

\begin{tabular}{|c|c|c|c|c|c|}
\hline Channel morphology & 1993 & 1999 & 2003 & 2006 & 2010 \\
\hline \multicolumn{6}{|c|}{ Segment 1} \\
\hline Segment length, in kilometers & 17.5 & 17.4 & 17.5 & 17.5 & 17.5 \\
\hline Average total channel width, in meters & 179 & 181 & 180 & 185 & 185 \\
\hline Average active channel width, in meters & 162 & 156 & 161 & 160 & 155 \\
\hline Average braided index, in number of channel threads & 1.12 & 1.15 & 1.11 & 1.14 & 1.18 \\
\hline Percent of cross sections that intersected incipient flood plain & 51.0 & 60.0 & 70.0 & 73.3 & 73.5 \\
\hline Percent of cross sections that intersected islands & 1.9 & 1.4 & 0.3 & 0.0 & 1.2 \\
\hline $\begin{array}{l}\text { Total non-active channel (incipient surface or island), in square meters } \\
\text { per river kilometer }\end{array}$ & 18,616 & 25,966 & 19,889 & 27,057 & 32,274 \\
\hline Incipient flood-plain surface area, in square meters per river kilometer & 18,046 & 25,352 & 19,863 & 27,057 & 31,759 \\
\hline In-channel island area, in square meters per river kilometer & 570 & 614 & 26 & 0 & 515 \\
\hline \multicolumn{6}{|c|}{ Segment 2} \\
\hline Segment length, in kilometers & 19.5 & 19.5 & 19.5 & 19.4 & 19.4 \\
\hline Average total channel width, in meters & 281 & 290 & 276 & 275 & 277 \\
\hline Average active channel width, in meters & 269 & 270 & 262 & 259 & 260 \\
\hline Average braided index, in number of channel threads & 1.18 & 1.10 & 1.18 & 1.12 & 1.18 \\
\hline Percent of cross sections that intersected incipient flood plain & 33.4 & 37.0 & 38.7 & 41.3 & 45.4 \\
\hline Percent of cross sections that intersected islands & 13.6 & 11.2 & 2.6 & 2.3 & 2.3 \\
\hline $\begin{array}{l}\text { Total non-active channel (incipient surface or island), in square meters } \\
\text { per river kilometer }\end{array}$ & 23,695 & 28,706 & 15,805 & 19,197 & 19,736 \\
\hline Incipient flood-plain surface area, in square meters per river kilometer & 15,067 & 21,705 & 14,584 & 18,012 & 18,519 \\
\hline In-channel island area, in square meters per river kilometer & 8,627 & 7,001 & 1,221 & 1,185 & 1,217 \\
\hline \multicolumn{6}{|c|}{ Segment 3} \\
\hline Segment length, in kilometers & 28 & 27.9 & 28 & 28 & 28 \\
\hline Average total channel width, in meters & 264 & 278 & 276 & 280 & 280 \\
\hline Average active channel width, in meters & 257 & 270 & 264 & 265 & 263 \\
\hline Average braided index, in number of channel threads & 1.18 & 1.16 & 1.25 & 1.18 & 1.22 \\
\hline Percent of cross sections that intersected incipient flood plain & 17.6 & 26.7 & 29.6 & 35.9 & 41.7 \\
\hline Percent of cross sections that intersected islands & 14.0 & 15.6 & 11.6 & 11.5 & 10.8 \\
\hline $\begin{array}{l}\text { Total non-active channel (incipient surface or island), in square meters } \\
\text { per river kilometer }\end{array}$ & 19,422 & 25,351 & 23,681 & 25,401 & 27,328 \\
\hline Incipient flood-plain surface area, in square meters per river kilometer & 6,771 & 9,029 & 12,849 & 15,100 & 18,195 \\
\hline In-channel island area, in square meters per river kilometer & 12,651 & 16,322 & 10,832 & 10,300 & 9,134 \\
\hline
\end{tabular}

measurements for 1993 and 2010 photography indicate that changes up to $5 \mathrm{~m}$ are within the uncertainty band (assuming errors were independent). The most noticeable changes in segment 1 were substantial areal increases in incipient flood-plain surfaces between 1993 and 1999 (40 percent; table 4) and again between 2003 and 2006. The increases in incipient flood-plain surface areas correspond to the small decrease in average active channel width during the study period. Between 1999 and 2003, many of the incipient flood-plain surface areas were reactivated in the river channel (22 percent decrease; table 4). After 2003, incipient flood-plain surface area once again increased so that by 2010 its area and average active channel width were both similar to their 1999 measures (table 4).
Segment 2.-The most substantial changes to segment 2 were measured between 1993 and 1999 and 1999 to 2003. Changes between subsequent pairs of study years were small. Between 1993 and 1999, total channel width increased by $9 \mathrm{~m}$ (3 percent) but the increase in average active channel width was insignificant (table 3 ), because the increase in the average total channel width was offset by a 44 percent increase in incipient flood-plain surface area (table 4). Between 1999 and 2003, there were decreases of $14 \mathrm{~m}$ (5 percent) and $8 \mathrm{~m}$ (3 percent) in average total channel width and average active channel width, respectively (table 4, fig. $8 B$ ). During this early phase of a dry period, island area decreased by 83 percent. 


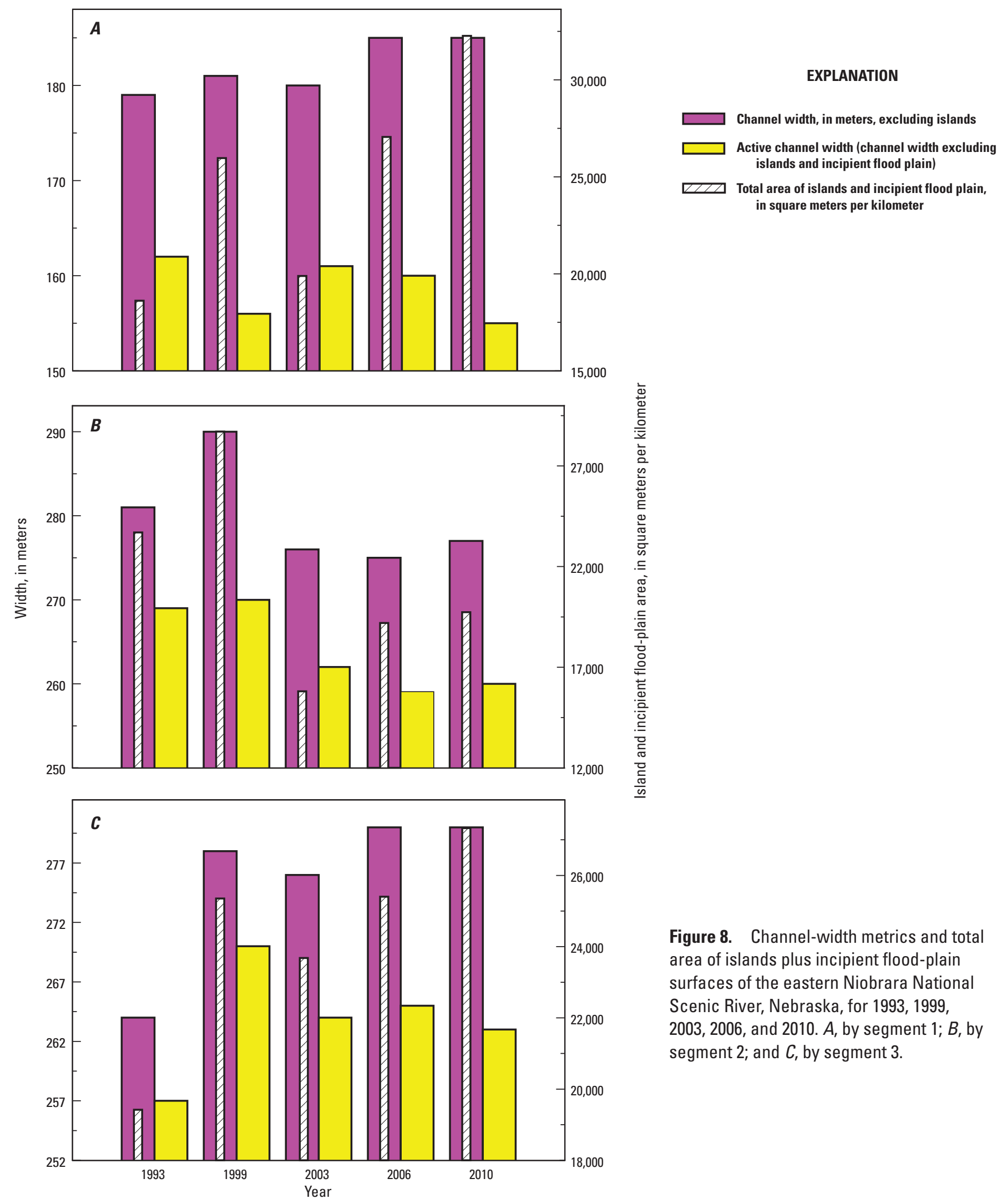


Visual observation of the aerial photographs verified that the bank attachment of large islands was the main contributor to decreases in channel width (total and active). After 2003, average channel width in segment 2 remained constant; that is, differences were within the measurement uncertainty (table 4). Because the decreases between 1999 and 2003 were greater than the increases between 1993 and 1999, the active channel of segment 2 experienced net narrowing of $9 \mathrm{~m}$ between 1993 and 2010.

The spatial frequency of incipient flood plain increased between 1999 and 2010 in segment 2 although the total area of incipient flood-plain surfaces did not. By 2010, 45 percent of cross sections intersected an incipient flood-plain surface compared to 37 percent in 1999 (table 4). However, incipient flood-plain surface area decreased by 15 percent between 1999 and 2010. Based on visual inspection of the aerial photographs, in 2010 there were more incipient flood-plain surfaces which were extensive longitudinally, but these features were not as wide laterally as the incipient flood-plain surfaces in 1999.

Segment 3.-Segment 3 underwent morphologic changes similar to those in segment 2. Average total channel width and average active channel width increased by $14 \mathrm{~m}$ (5 percent) and $13 \mathrm{~m}$ (5 percent), respectively, between 1993 and 1999 (table 4). Between 1999 and 2003, average total channel width and average active channel width decreased. The decreases of $2 \mathrm{~m}$ (within measurement uncertainty) and $6 \mathrm{~m}$ ( 2 percent) were not as substantial as the increases during the previous period and, as mentioned in the "Statistical Comparisons" section, these were not considered statistically significant. Decreases in average total channel width coincided with a decrease in island area, similar to segment 2, but the decrease in island area was not as substantial (34 percent decrease compared to 83 percent decrease for segment 2). Channel morphologic changes were small after 2003 with no changes in average channel width of more than 1.5 percent, which allowed channel widths to have small net increases overall during 1993-2010 (table 4). The area of incipient flood-plain surfaces steadily increased during the study period, and by 2010, incipient flood-plain surface area was 169 percent larger than in 1993 and 42 percent of all cross sections intersected incipient flood-plain surfaces compared to 18 percent in 1993 (table 4). This trend coincided with a net decrease in area of islands so active channel width remained steady through 2010 (fig. 8C).

\section{Cross-Sectional Width Analysis}

Analysis of individual channel cross sections constructed in the GIS at fixed locations (using the 1993 channel centerline) indicated that morphologic changes in channel width (total channel width and active channel width) between study years were large at some individual cross sections even though the segments (discussed in the "Channel Metrics" section) as a whole did not have large changes. Cross-section analysis indicated that the largest changes in channel width were measured between 1993 and 1999, and between 1999 and 2003 (figs. 9-11). This pattern was consistent with the changes noted at the segment scale in the previous "Channel Metrics" section.

Although change in average total and active channel width between any consecutive pair of study years was never greater than 5 percent (table 4), there were many individual cross sections in each segment that had large increases or decreases in channel width (large change being defined hereinafter as a change of 25 percent or more between consecutive studied years), indicating the Niobrara River's channelforming and bank-eroding processes are engaged in a dynamic struggle. Although average channel width as a whole in segment 1 did not change substantially (as noted in the "Channel Metrics" section), the time series of cross-sectional active channel-width measurements indicated that many individual segment 1 cross sections experienced large changes, both decreases and increases between all compared study years (fig. $9 A-B$ ). In segment 2, at least 3 percent of cross sections indicated large decreases in active channel width between 1993 and 1999, and many more large decreases between 1999 and 2003, but large changes after 2003 were more evenly balanced between increases and decreases (fig. 10B). In segment 3, large changes in active channel width were measured in 7 percent of cross sections between 1993 and 1999, but its cross sections did not indicate many large changes thereafter (fig. 11B). Fifteen percent of cross sections in segment 1 had large decreases in active channel width between 1993 and 1999, whereas 10 percent of its cross sections had large increases (fig. 9B), which generally corroborates the discovery of balancing gains and losses noted in the "Channel Metrics" section. Only one period (between 2003 and 2006) had fewer than 10 percent of segment- 1 cross sections with large changes in active channel width, which indicates a very fluid segment of the river that is continually reworking its sediment by constructing and altering its flood plain.

Total channel width changes during 1993-99. - Large increases in total channel width were measured at many fixed cross sections from 1993 to 1999 . The majority of the large increases in total channel width were attributed to bank and island erosion, and other large increases were related to channel avulsion between 1993 and 1999, which left new incipient flood-plain surfaces behind. An example of an area where bank erosion was evident is shown for segment 1 in figures 12-13. Segments 1 and 3 had the greatest number of large changes in total channel width with 9 and 12 percent of cross sections widening by at least 25 percent, respectively (figs. $9 A$ and $11 A$ ). Only 3 percent of cross sections in segment 2 had large increases in total channel width. Large increases of total channel width in segment 1 were offset by large losses at 11 percent of cross sections. Segments 2 and 3 did not have similar offsetting losses as only 0.1 percent and 0.3 percent, respectively, of cross sections experienced large losses (figs. $10 A$ and $11 A$ ).

Total channel width changes during 1999-2003.-From 1999 to 2003, many cross sections in all three segments experienced narrowing. The largest decreases in total channel 


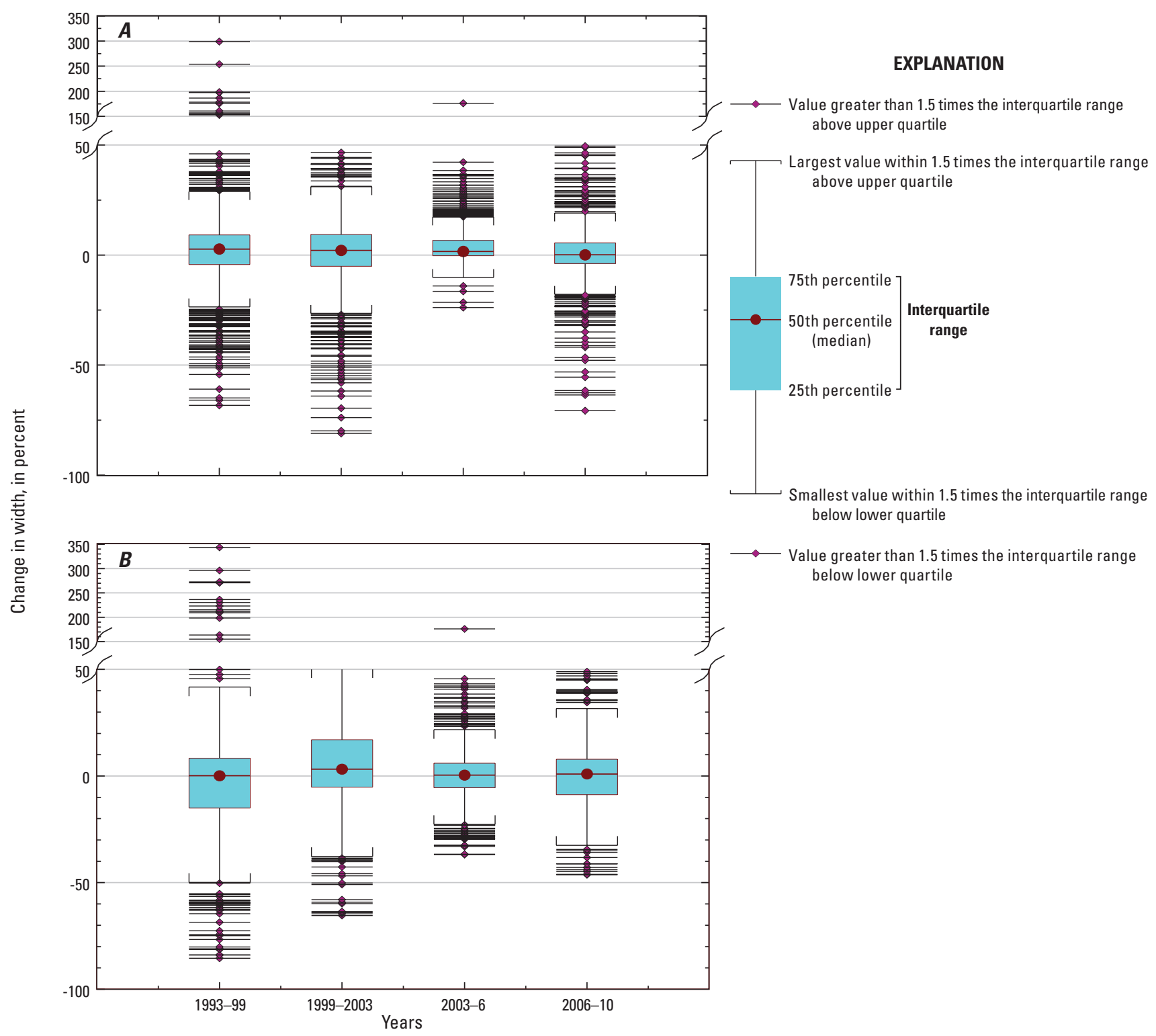

Figure 9. Frequency distribution of cross-section scale changes in channel-width metrics from aerial photography between consecutive pairs of study years, study segment 1, eastern Niobrara National Scenic River, Nebraska, 1993-2010. A, Total channel width and $B$, active channel width. 


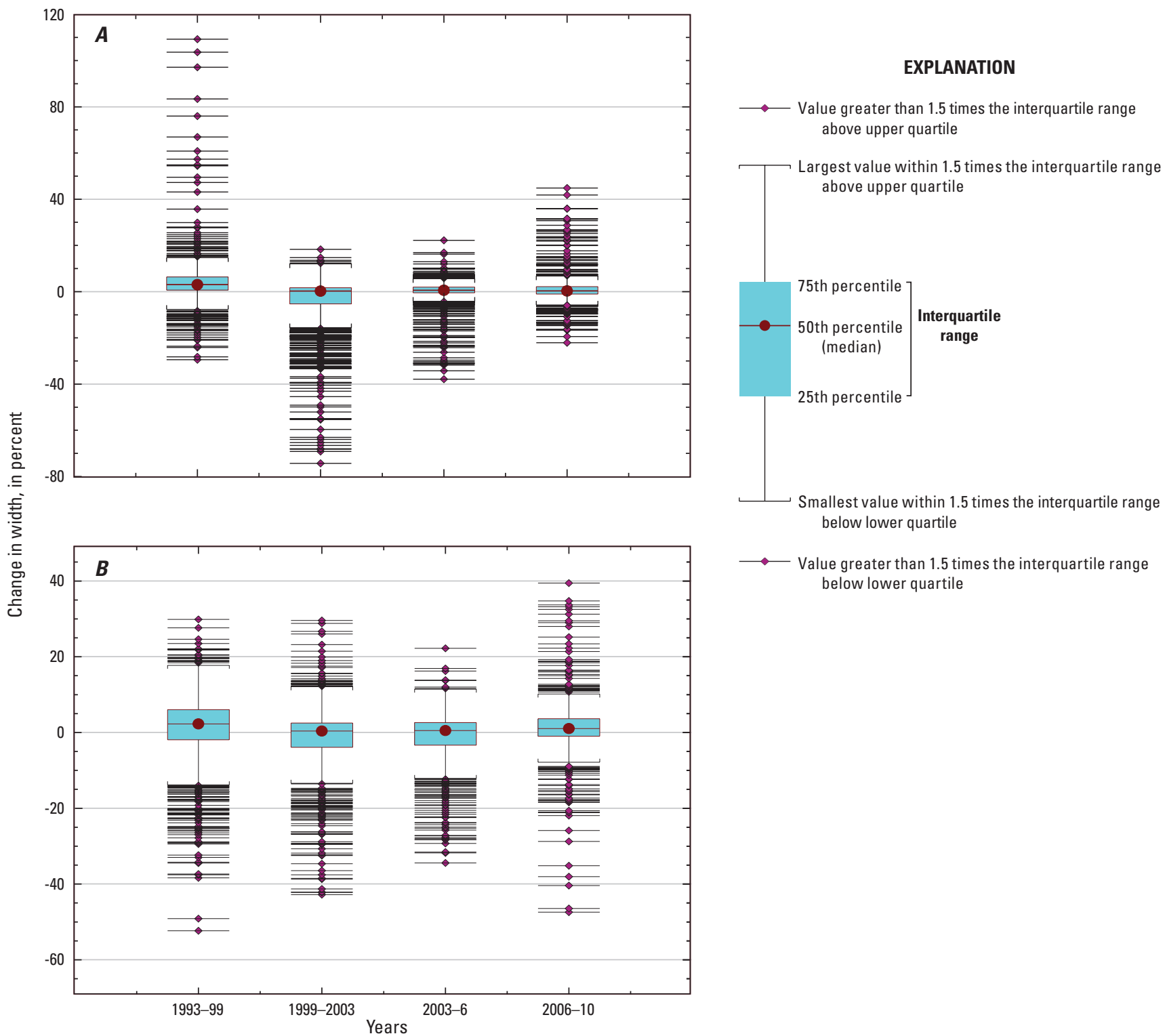

Figure 10. Frequency distribution of cross-section scale changes in channel-width metrics from aerial photography between consecutive pairs of study years, study segment 2, eastern Niobrara National Scenic River, Nebraska, 1993-2010. A, Total channel width and $B$, active channel width. 


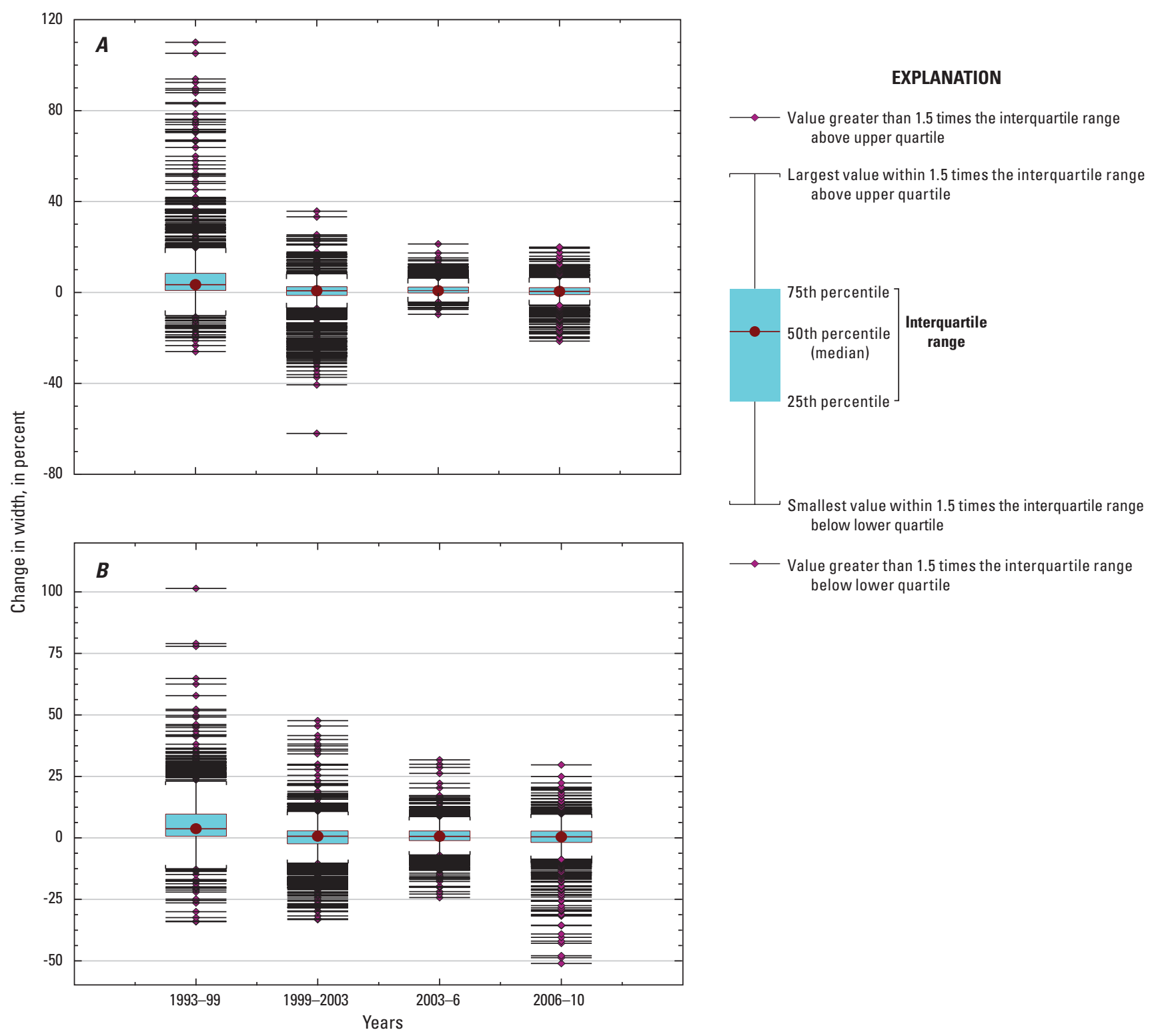

Figure 11. Frequency distribution of cross-section scale changes in channel-width metrics from aerial photography between consecutive pairs of study years, study segment 3, eastern Niobrara National Scenic River, Nebraska, 1993-2010. A, Total channel width and $B$, active channel width. 


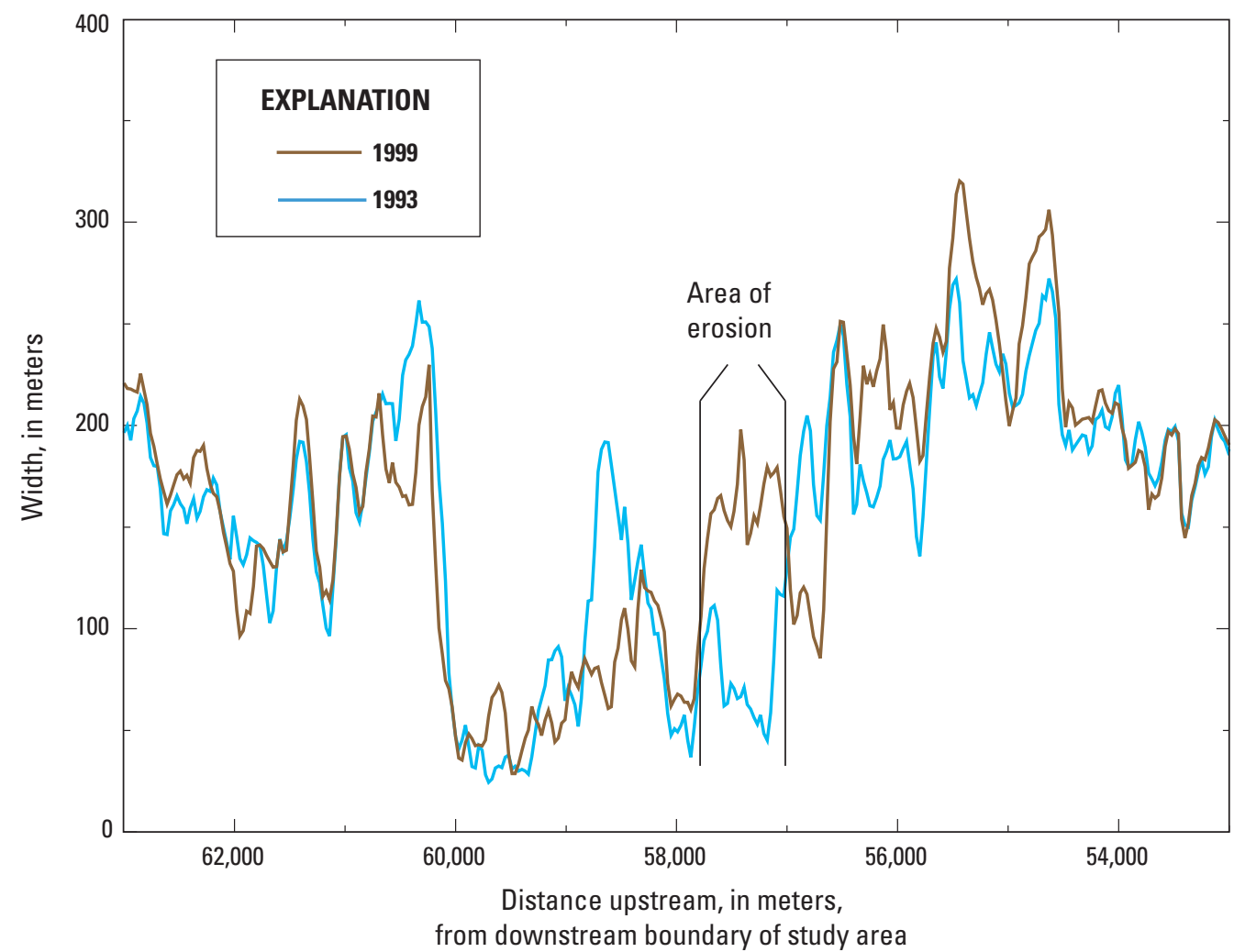

Figure 12. Longitudinal trend in total channel width for reach in study segment $1,53,000$ to 63,000 meters upstream from study area boundary, eastern Niobrara National Scenic River, Nebraska, 1993-99, highlighting an area of bank erosion. width at individual channel cross sections were measured during this period. Large decreases in total channel width between 1999 and 2003 were related to channel narrowing as a result of flood-plain encroachment (figs. 14 and 15). Eight percent of cross sections in segments 1 and 2 had large decreases in width (figs. 9 and 10). Only 3 percent of cross sections in segment 3 had large total channel width decreases (fig. 11). The narrowing in segment 1 was offset by large increases at 9 percent of cross sections. Only 0.3 percent of segment 3 had large total channel width increases between 1999 and 2003 and no large increases in channel width were measured in segment 2 (figs. 10 and 11).

Morphologic changes in segment 3 were generally restricted to the same cross sections, whereas in segments 1 and 2 the locations of changes fluctuated. Of the cross sections in segment 3 that had large decreases in total channel width between 1999 and 2003, 71 percent had large increases between 1993 and 1999 (fig. 11). Comparatively, in segments 1 and 2, 8 and 29 percent, respectively, of cross sections with large decreases in total channel width between 1999 and 2003 had large increases in channel width between 1993 and 1999. Based on visual observation of the aerial photographs, the areas susceptible to change in segment 3 were located in depositional areas of small inflowing tributaries or areas where the river widened abruptly.

Total channel width changes after 2003-Between 2003 and 2006 and from 2006 to 2010, there were fewer large changes than for the previous analysis periods (figs. 9-11). No large changes in total channel width were measured in segment 3 during these periods (fig. 11). Segment 1 was most geomorphically active as 3 percent of cross sections increased in total channel width between 2003 and 2006, and 6 percent of cross sections increased in total channel width between 2006 and 2010 (fig. 9). No offsetting decreases in total channel width were measured in segment 1 between 2003 and 2006 but 5 percent of cross sections decreased in total channel width between 2006 and 2010 (fig. 9). Two percent of the cross sections in segment 2 had large decreases in total channel width between 2003 and 2006 followed by large increases in total channel width at 2 percent of cross sections between 2006 and 2010 (fig. 10).

\section{Effects of Streamflows on Stream-Channel Morphology Changes}

As discussed in the foregoing "Channel Morphology" subsections, there were some changes in channel width and incipient flood-plain surface area in each segment, especially between 1993 and 1999 and between 1999 and 2003. Overall, these percentage changes were small at the segment scale; however, large changes were measured at many fixed cross sections in all three segments. Moreover, not all three segments responded in the same way. Responses in segments 2 and 3 generally were similar, but the responses in segment 1 seemed independent, which could be related to the instability of the channel that was identified in the "Cross-Sectional Width Analysis" section. The only consistent changes in all three segments were increases in incipient flood-plain surface area between 1993 and 1999 and between 2003 and 2006, and a decrease in 

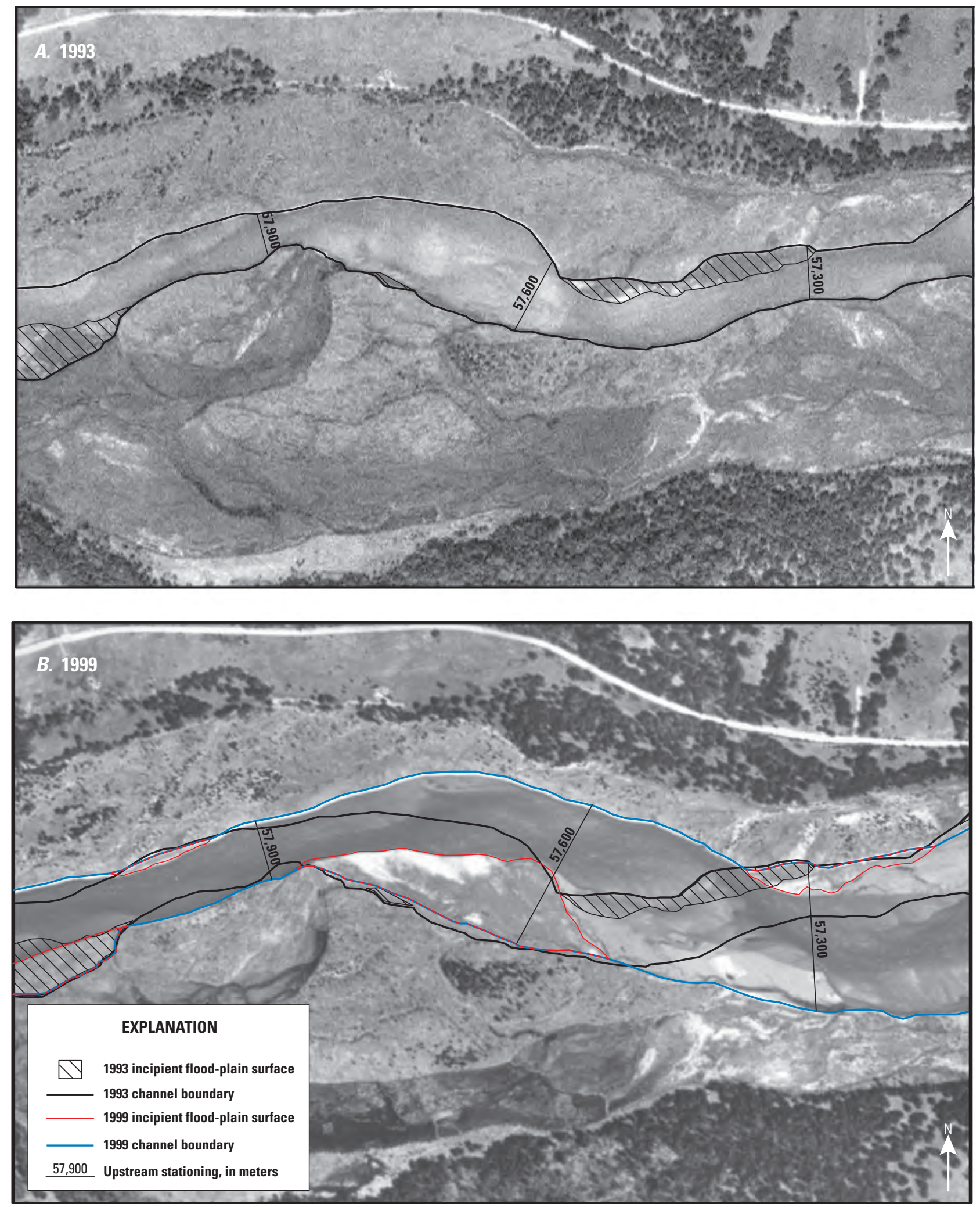

Base from U.S. Geological Survey aerial photographs 1993 2-meter resolution and 1999 1-meter resolution

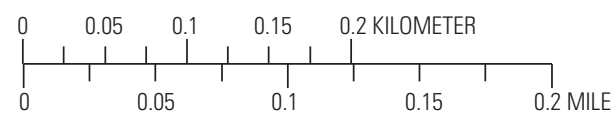

Figure 13. Channel change delineated on aerial photographs of eastern Niobrara National Scenic River, Nebraska, highlighting areas that underwent substantial bank erosion in a part of segment 1. $A, 1993$ and $B, 1999$. 


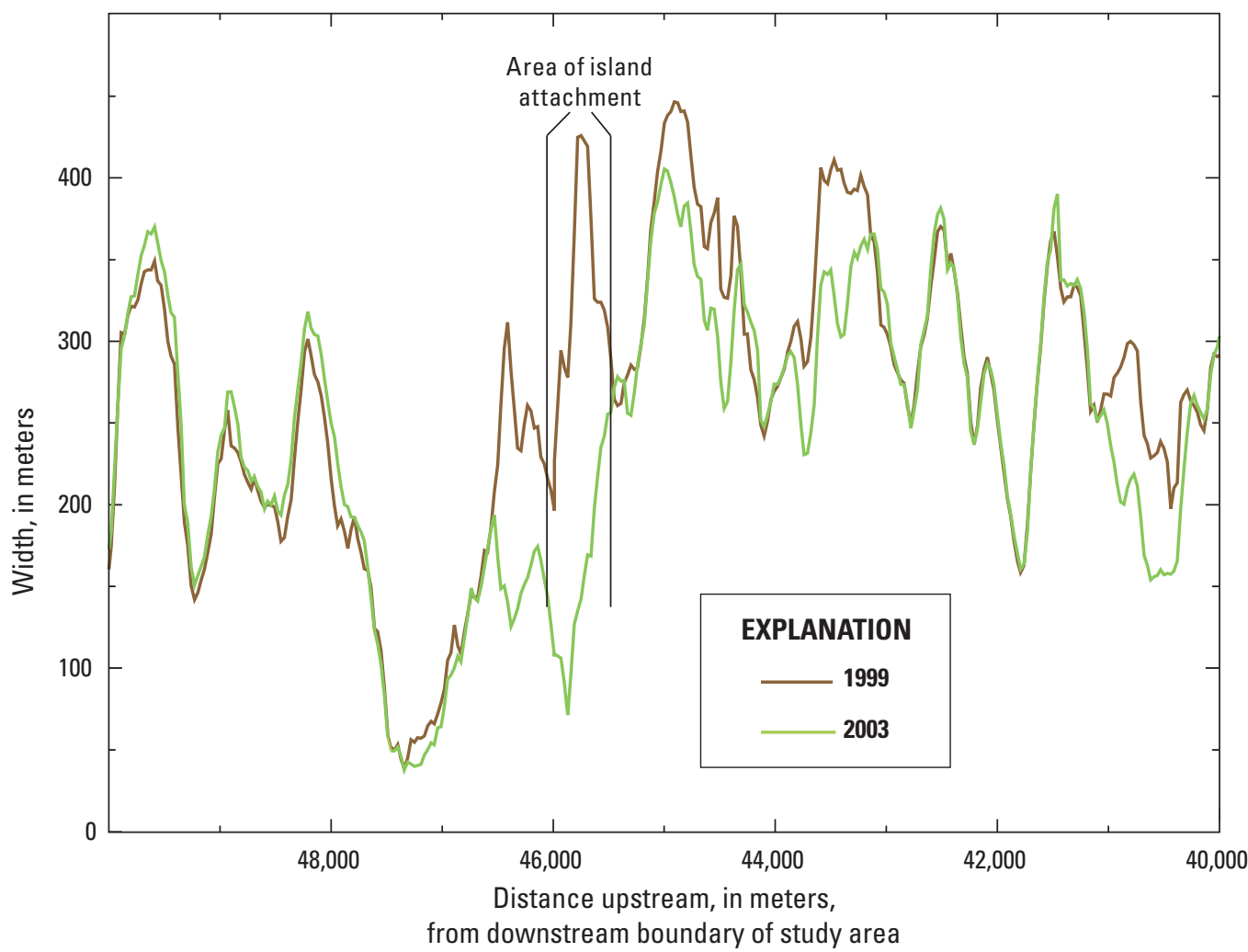

Figure 14. Longitudinal trend in total channel width for reach in study segments 1 and 2, 40,000 to 50,000 meters upstream from study area boundary, eastern Niobrara National Scenic River, Nebraska, 1999-2003, highlighting an area of island attachment to bank. island area between 1999 and 2003 (table 4). Each of these consistent changes among the study segments corresponded to changes in streamflow conditions, as will be next discussed.

The feature classification accuracy for 1993 and 1999 photography (table 1) indicate that changes up to $5 \mathrm{~m}$ are within the uncertainty band, so the widening of the total channel at segments 2 and 3 during 1993-99 is considered real, but its change at segment $1(2 \mathrm{~m})$ was less than measurement uncertainty. The increases in channel widths from 1993 to 1999 could be related to the extended duration of higher streamflows throughout the period, the large flood event of 1994, or effects from the ice breakup related to the large 1994 flood event. Higher flows correspond to swifter current velocity, which corresponds with generally higher rates of bank erosion and greater bed shear stress that inhibits vegetation from stabilizing bars. Large floods usually erode flood plains at cutbanks and construct new depositional surfaces (herein referred to as "incipient flood plains") that generally will aggrade over time to the elevation of the modern flood plain (Wohl, 2014). These processes, along with localized changes in slope and sediment-grain size, could explain the channel widening at the segment scale as well as the channel erosion measured at the cross-section scale. Alternatively, the channel widening could have resulted from a combination of the flood pulse followed by continued wide-channel maintenance facilitated by greater duration of high streamflows. The 1994 flood was not only a large event, but also was a large ice-jam event. Ice-jam floods or ice-dam breakout floods can have higher flood stages than ice-free floods, and based on stage records this was the case with the 1994 event. These types of floods may leave a depositional record at an elevation higher than the modern flood plain. Ice jams reportedly have created new channels and eroded gulleys in meander-lobe flood plains and braided rivers (Smith and Pearce, 2002), which could explain the channel widening and increases in incipient flood-plain surface area that were measured between 1993 and 1999. If ice jams during the 1994 flood created new channels occupied only at higher stages than those of flows normally contained within the main channel, the appearance of a new incipient flood-plain surface is logical in 1999 photography, when streamflow had for several years not reoccupied these chutes.

Channel width initially narrowed from 1999 to 2003 in response to extended duration of summer low flows. This was related to at least two processes by which channels narrow: (1) encroachment of banks, some of which involves attachment (accretion) of islands as indicated by the decrease in island area during this time period; and (2) conversion of incipient flood-plain surfaces to mature flood plain as they become stabilized by the successional trend of riparian vegetation, possibly undergo further aggradation, and become incorporated within the existent flood plain. Although extended periods of low summer flow continued (especially in 2006), no additional narrowing was measured. Summer streamflow at the Niobrara River near Sparks was typically $450 \mathrm{ft}^{3} / \mathrm{s}$ or greater after 2003 (fig. 6A). This magnitude of streamflow combined with the downstream inflows of Plum Creek and Long Pine Creek (typically $160 \mathrm{ft}^{3} / \mathrm{s}$ for Long Pine, and $110 \mathrm{ft}^{3} / \mathrm{s}$ for Plum Creek; figs. $7 A$ and $5 C$ ) likely kept the duration of summer flows above $700 \mathrm{ft}^{3} / \mathrm{s}$ at a high frequency. This amount of flow was enough to prevent further narrowing after 2003. Segment 

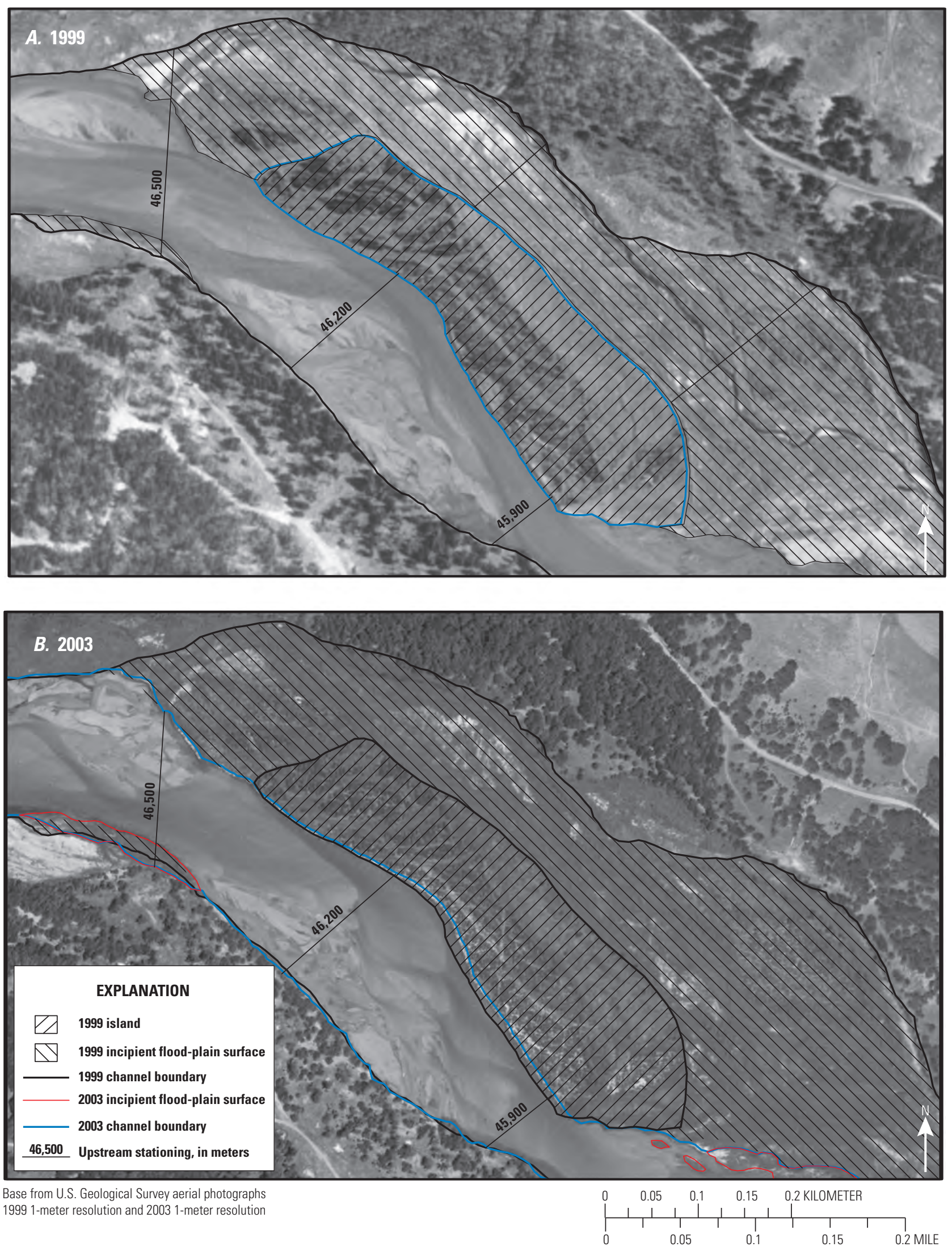

Figure 15. Channel change delineated on aerial photographs of eastern Niobrara National Scenic River, Nebraska, highlighting an area of island attachment to a bank in a part of segment 1. $A, 1999$ and $B, 2003$. 
1 was about $100 \mathrm{~m}$ narrower than segments 2 and 3 , and thus may have previously undergone the channel-narrowing processes outlined above and has approached an equilibrium between those processes and the widening processes.

\section{Summary}

The Niobrara River is an important and valuable economic and ecological resource in northern Nebraska. It has a diverse ecosystem with many plant and animal species and is used as a stopover for migratory bird species that include several threatened or endangered species. It provides opportunities for ecotourism and recreational boating, and supports hydroelectric power and agriculture. Since its National Scenic River designation in 1991, a 122-kilometer $(\mathrm{km})$ reach of the river has been managed jointly by the U.S. Fish and Wildlife Service and the National Park Service. The U.S. Geological Survey (USGS), in cooperation with the National Park Service, investigated the effects of potential changes in summer streamflow on channel morphology in the eastern region of the Niobrara National Scenic River. The goal was to assess how potential decreases in summer streamflow resulting from a postulated increase of consumptive water uses may affect the channel morphology of the Niobrara National Scenic River that provides important nesting habitat for migratory bird species.

The study focused on three segments within a $65-\mathrm{km}$ eastern segment of the Niobrara National Scenic River. The studied main-stem segments were separated at the confluences with two tributaries, Plum Creek and Long Pine Creek. With an overall temporal scope of 1988-2010 that includes a short interval preceding and a long interval following the Niobrara National Scenic River Designation Act of 1991, the study analyzed five separate time periods: 1988-93, 1994-99, 2000-3, 2004-6, and 2007-10, each of which ended with a year in which aerial photography coverage was available.

Flow duration was analyzed for a USGS streamgage along the Niobrara River upstream from the study area as well as for two tributaries (Plum Creek and Long Pine Creek) within the study area. Late summer flows (July, August, and September) were targeted for analysis based on monthly flow statistics indicating that median flows were lowest at Niobrara River near Sparks, Nebraska (USGS site 06461500) during those 3 months. Flood-frequency analysis was completed to compute a bankfull discharge (1.5-year flood), which was used to compare with peak flows during the study period.

Flow analysis indicated that the Niobrara River had high flows, including a large flood peak (1994) during the 1994-99 period and lower summer flows during the 2000-3 and 2004-6 periods. Summer streamflow for Long Pine Creek was also highest during the 1994-99 period. Summer streamflow was lower for Long Pine Creek during the 1988-93, 2000-3 and 2004-6 study time periods but only 3 years (1989, 2002 and 2006) had summer median streamflow below post-regulation median summer streamflow and the departures were less than 8 percent.

Aerial photographs taken after the Niobrara River was designated a National Scenic River were used to determine changes in channel characteristics. Photographs from 1993, 1999, 2003, 2006, and 2010 were analyzed. Channel metrics of width (total channel width, active channel width), area of islands and incipient flood-plain surfaces, and braided index were computed for each photography year and summarized by the three individual river segments. Additionally, at fixed-location cross sections, photography analysis identified localized geomorphic change to infer processes. Accuracy of geomorphic feature classification was estimated and the rootmean-square difference (RMSD) between aerial photographs was calculated to determine associated errors in channel metric calculations. The horizontal accuracy of boundaries delineated in the classification was estimated as 5 meters (m) for boundaries based on 1993 aerial photography and $4 \mathrm{~m}$ for all other aerial photography. The RMSD between aerial photography years ranged from $3.04 \mathrm{~m}$ to $4.16 \mathrm{~m}$. The RMSD is only relevant to comparisons of the fixed-location cross section because it compared co-located cross sections, whereas the summary of channel metrics was concerned with average characteristics throughout an entire river segment.

Statistical analysis using the Kruskal-Wallis test showed that segments 2 and 3 had significant differences in the distributions of calculated active channel width. Further analysis using the Wilcoxon rank sum test determined that the significant differences were between the 1999 and 2003 active channel-width datasets for segment 2, and the 1993 and 1999 active channel datasets for segment 3 .

The largest changes in channel metrics were measured between 1993 and 1999 and 1999 and 2003. These included measurable increases in channel width in segments 2 and 3 between 1993 and 1999 and subsequent decreases between 1999 and 2003. Between 1993 and 1999, total channel width increased by 3 percent in segment 2 and 5 percent in segment 3 , and active channel width increased by 5 percent in segment 3. Changes in channel width between 1999 and 2003 included a decrease in average total channel width of $14 \mathrm{~m} \mathrm{(5}$ percent) in segment 2 , and a decrease in active channel widths of $8 \mathrm{~m}$ ( 3 percent) and $6 \mathrm{~m}$ ( 2 percent $)$ in segments 2 and 3, respectively.

Large changes were measured between 1993 and 1999, and between 1999 and 2003, at many of the fixed-location cross sections. Large changes (that is, greater than 25 percent) in total channel width were measured in all three segments between 1993 and 1999 and again between 1999 and 2003; large increases were dominant in the earlier period, and large decreases were dominant between 1999 and 2003 except in segment 1 . These patterns reflected the analysis results reported in the segment average summaries. Segment 1 was the most susceptible to localized changes as there was only one period (between 2003 and 2006) in which large changes in active channel width were measured in fewer than 10 percent of the cross sections. 
Changes in channel metrics generally corresponded to changes in streamflow conditions, but other than changes in incipient flood-plain area, these changes were small and were not measured in all three segments simultaneously. Increases in total channel width (except in segment 1) between 1993 and 1999 corresponded to increases in streamflow. A large ice-jam flood in 1994 could also have contributed to channel widening. The flood along with the increase in streamflows also corresponded to an increase in incipient flood-plain area. This increase indicated the flood and high streamflows created new depositional surfaces. Channel narrowing (except in segment 1) between 1999 and 2003, which was caused by encroachment of banks, some of which involved attachment (accretion) of islands, corresponded to lower summer streamflows and extended durations of very low summer streamflow. Although the pattern of low summer streamflow and extended durations of very low summer streamflow continued during the 2004-6 period and at the beginning of the 2007-10 period, no further narrowing was measured. Consistent tributary summer inflows help to explain the resistance of segments 2 and 3 to further narrowing. Because segment 1 is already much narrower than segments 2 and 3, its average current velocity is likely to be swifter and, therefore, competent to offset further processes that led to its narrowness.

\section{References Cited}

Alexander, J.S., Zelt, R.B., and Schaepe, N.J., 2009, Geomorphic segmentation, hydraulic geometry, and hydraulic microhabitats of the Niobrara River, Nebraska-Methods and initial results: U.S. Geological Survey Scientific Investigations Report 2009-5008, 34 p.

Alexander, J.S., Zelt, R.B., and Schaepe, N.J., 2010, Hydrogeomorphic and hydraulic habitats of the Niobrara River, Nebraska-With special emphasis on the Niobrara National Scenic River: U.S. Geological Survey Scientific Investigations Report 2010-5141, 62 p.

Alley, W.M., 1984, The Palmer Drought Severity Index-Limitations and assumptions: Journal of Climate and Applied Meteorology, v. 23, p. 1100-1109.

Bleed, A., and Flowerday, C., 1990, An atlas of the Sand Hills: University of Nebraska-Lincoln, Resource Atlas 5a, 265 p.

Buchanan, J.P., 1981, Channel morphology and sedimentary facies of the Niobrara River, north-central Nebraska: Fort Collins, Colo., Colorado State University, M.S. thesis, $126 \mathrm{p}$.

Buchanan, J.P., 1994, River channel changes through timeRed, Canadian, and Niobrara Rivers on the Great Plains, chap. 14 of Schumm, S.A., and Winkley, B.R., eds., The variability of large alluvial rivers: New York, ASCE Press, p. 285-312.
Buchanan, J.P., and Schumm, S.A., 1990, The riverscapeNiobrara River, Chap. 12 of Wolman, M.G., and Riggs, H.C., eds., Surface water hydrology - The geology of North America: Geological Society of America, v. 1, p. 314-321.

Bureau of Reclamation, 2013, Ainsworth unit development: Bureau of Reclamation project details, accessed January 2015 at http://www.usbr.gov/projects/Project.jsp?proj_ Name $=$ Ainsworth + Unit.

Dunn, R., Harrison, A.R., and White, J.C., 1990, Positional accuracy and measurement error in digital databases of land use-An empirical study: International Journal of Geographical Information Systems, p. 385-398.

Ducey, J., 1989, Birds of the Niobrara River valley, Nebraska: Transactions of the Nebraska Academy of Sciences and Affiliated Societies, Paper 166, 25 p.

Dunne, T., and Leopold, L.B., 1978, Water in environmental planning: New York, Freeman and Company, 305 p.

Elliott, C.M., and Jacobson, R.B., 2006, Geomorphic classification and assessment of channel dynamics in the Missouri National Recreational River, South Dakota and Nebraska: U.S. Geological Survey Scientific Investigations Report 2006-5313, 66 p.

Fenneman, N.M., 1946, Physical divisions of the United States: Washington D.C., U.S. Geological Survey special map, scale 1:7,000,000.

Fischer, E.E., 1987, Estimation of streamflow characteristics and assessment of trends in the Niobrara River at Mariaville, Nebraska: U.S. Geological Survey Water-Resources Investigations Report 87-4073, $25 \mathrm{p}$.

Fishman, G.S., 1995, Monte Carlo-Concepts, algorithms, and applications: Springer Series in Operations Research, $689 \mathrm{p}$.

Helsel, D.R., and Hirsch, R.M., 2002, Statistical methods in water resources: U.S. Geological Survey Techniques of Water-Resources Investigations, book 4, chap. A3, 522 p.

Hortness, J.E., and Berenbrock, Charles, 2004, Estimating the magnitude of bankfull flows for streams in Idaho: U.S. Geological Survey Water-Resources Investigations Report 03-4261, $42 \mathrm{p}$.

Interagency Advisory Committee on Water Data, 1982, Guidelines for determining flood flow frequency: Washington, D.C., Hydrology Subcommittee, Bulletin 17B (revised and corrected), 28 p., 14 appendices, accessed September 2014 at http://water.usgs.gov/osw/bulletin17b/dl_flow.pdf. 
Istanbulluoglu, E., 2008, Hydrological data analysis of the Niobrara River: University of Nebraska-Lincoln, Final project report to Nebraska Game and Parks Commission and National Park Service, 81 p., accessed May 2013 at https://outdoornebraska.ne.gov/conservation/InstreamFlow/ RiverFlowProject/Niobrara/2014/NGPC_Hydrology\%20 Report_2008.pdf.

Istanbulluoglu, E., Wang, T., Wright, O.M., and Lenters, J.D., 2012, Interpretation of hydrologic trends from a water balance perspective - The role of groundwater storage in the Budyko hypothesis: Water Resource Research, v. 48, accessed January 2014 at http://onlinelibrary.wiley.com/ doi/10.1029/2010WR010100/abstract.

Johnson, W.C., 1994, Woodland expansions in the Platte River, Nebraska-Patterns and causes: Ecological Monographs, v. 64 , no. 1 , p. 45-84.

Krstolic, J.L., Hayes, D.C., and Ruhl, P.M., 2006, Physical habitat classification and instream flow modeling to determine habitat availability during low-flow periods, North Fork Shenandoah River, Virginia: U.S. Geological Survey Scientific Investigations Report 2006-5025, 63 p.

Krstolic, J.L., and Ramey, R.C., 2012, South Fork Shenandoah River habitat-flow modeling to determine ecological and recreational characteristics during low-flow periods: U.S. Geological Survey Scientific Investigations Report 2012-5081, 64 p. [Also available at http://pubs.usgs.gov/ $\operatorname{sir} / 2012 / 5081 /$.

Lauer, J.W., 2006, Stream restoration toolbox: National Center for Earth-Surface Dynamics, accessed August 2014 at http:// www.nced.umn.edu/content/stream-restoration-toolbox.

Leopold, L.B., 1994, A view of the river: Cambridge, Mass., Harvard University Press, 298 p.

Merrick and Co., 2012, Natural Resource Conservation Survey LIDAR Digital Elevation Models for Nebraska-2 meter, 2012: Aurora, Colo., Merrick and Co., raster data in .img format, accessed July 2014 at http://dnr.ne.gov/lidar2-meter-2009-2012.

National Oceanic and Atmospheric Administration, 2014, Gridded climate divisional dataset: National Oceanic and Atmospheric Administration National Climatic Data Center, accessed May 2014 at https://gis.ncdc.noaa.gov/ geoportal/catalog/search/resource/details.page?id=gov.noaa. ncdc:C00005.

Omernik, J.M., 1987, Ecoregions of the conterminous United States: Annals of the Association of American Geographers, v. 77, no.1, p. 118-125, 1 pl., scale 1:7,500,000.

Palmer, W.C., 1965, Meteorological drought: U.S. Weather Bureau, Research Paper No. 45, 59 p.
Powell, J.W., 1879, Lands of the arid region of the United States with a more detailed account of the lands of Utah $(2 \mathrm{~d}$ ed.): U.S. Geological Survey, U.S. geographical and geological survey of the Rocky Mountain region, 203 p.

Reinfelds, I., and Nanson, G., 1993, Formation of braided river floodplains, Waimakariri River, New Zealand: Sedimentology, v. 40, p. 1113-1127.

Schumm, S.A., 2005, River variability and complexity: Cambridge, United Kingdom, Cambridge University Press, 234 p.

Shaffer, F.B., 1975, History of irrigation and characteristics of streamflow in northern Nebraska: U.S. Geological Survey Open-File Report 7501, 114 p.

Shultz, Steven, 2010, The extent and value of agricultural, municipal, and industrial water use in the Niobrara Basin: Final Research Report, 68 p.

Smith, D.G., and Pearce, C.M., 2002, Ice jam-caused fluvial gullies and scour holes on northern river flood plains: Geomorphology, v. 42, no. 1-2, p. 85-95.

Soenksen, P.J., Flyr, B.B., Alexander, J.S., and Schaepe, N.J., 2010, Streamflow gains and losses in the Niobrara River basin, Nebraska, 1980 and 2009: Journal of Environmental Hydrology, v. 18, no. 11, 30 p.

Stanton, J.S., Peterson, S.M., and Fienen, M.N., 2010, Simulation of groundwater flow and effects of groundwater irrigation on stream base flow in the Elkhorn and Loup River Basins, Nebraska, 1895-2055-Phase two: U.S. Geological Survey Scientific Investigations Report 2010-5149, 78 p. with app.

Szilagyi, J., Harvey, F.E., and Ayers, J.F., 2005, Regional estimation of total recharge to ground water in Nebraska: Groundwater, v. 43, no. 1, p. 63-69.

TIBCO Software, Inc., 2008, TIBCO Spotfire $S+\circledR 8.1$ for Windows ${ }^{\circledR}$ user's guide: TIBCO Software Inc. [variously paged].

U.S. Department of Agriculture, Farm Service Agency, Aerial Photography Field Office, 2003, various USDA-FSAAPFO Digital Ortho Mosaics from the National Agriculture Imagery Program (NAIP): Salt Lake City, Utah, accessed February 2008 at https://gdg.sc.egov.usda.gov/.

U.S. Department of Agriculture, Farm Service Agency, Aerial Photography Field Office, 2007, various USDA-FSAAPFO Digital Ortho Mosaics from the National Agriculture Imagery Program (NAIP): Salt Lake City, Utah, accessed May14, 2012 at https://gdg.sc.egov.usda.gov/. 
U.S. Department of Agriculture, Farm Service Agency, Aerial Photography Field Office, 2010, various USDA-FSA-APFO Digital Ortho Mosaics from the National Agriculture Imagery Program (NAIP): Salt Lake City, Utah, accessed May 15, 2012, at https://gdg.sc.egov.usda.gov/.

U.S. Geological Survey, 1970, Land resource regions and major land resource areas of the United States: digital data, adapted from U.S. Soil Conservation Service, 1:2,000,000 scale, accessed November 25, 2002, at http://water.usgs. gov/lookup/getspatial?mlra.

U.S. Geological Survey, 1993, various aerial photographs from the National Aerial Photography Program (NAPP): Sioux Falls, S. Dak., accessed May 14, 2012, at http://earthexplorer.usgs.gov/.

U.S. Geological Survey, 1999, various aerial photographs from the National Aerial Photography Program (NAPP): Sioux Falls, S. Dak., accessed May, 13 2008, at http://earthexplorer.usgs.gov/.

U.S. Geological Survey, 2015, National Water Information System (NWISWeb): U.S. Geological Survey database, accessed March 31, 2015, at http://waterdata.usgs.gov/ nwis/.
U.S. Geological Survey and U.S. Department of Agriculture, 2008, Watershed boundary dataset: digital data, 1:24,000 scale, accessed September 5, 2008, at http://nhd.usgs.gov/ wbd.html.

Veilleux, A.G., Cohn, T.A., Flynn, K.M., Mason, R.R., Jr., and Hummel, P.R., 2014, Estimating magnitude and frequency of floods using the PeakFQ 7.0 program: U.S. Geological Survey Fact Sheet 2013-3108, 2 p. [Also available at http:// pubs.usgs.gov/fs/2013/3108/.]

Wang, T.E., Istanbulluoglu, E., Lenters, J., and Scott, D., 2009, On the role of groundwater and soil texture in the regional water balance-An investigation of the Nebraska Sand Hills, USA: Water Resources Research, v. 45, accessed April 2015 at http://watercenter.unl.edu/ResearchDB/publications/Lenters_Groundwater.pdf.

Wohl, Ellen, 2014, Rivers in the landscape-Science and management: Chichister, West Sussex, United Kingdom, John Wiley and Sons, 318 p.
Publishing support provided by:
Rolla Publishing Service Center
For more information concerning this publication, contact:
Director, USGS Nebraska Water Science Center
5231 South 19th Street
Lincoln, Nebraska 68512
(402) 328-4100
Or visit the Nebraska Water Science Center Web site at:
http://ne.water.usgs.gov/ 



\section{$\frac{\mathbb{2}}{\mathrm{C}}$}

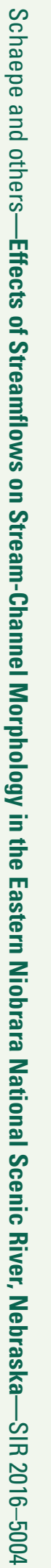

